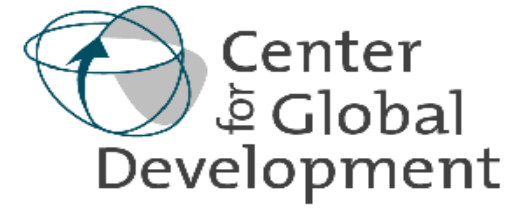

\section{Working Paper Number 155 \\ November 2008 \\ Thought for Food: The Challenges of Coping with Soaring Food Prices \\ By Nora Lustig}

Summary
World food commodities prices increased 130 percent from January 2002 to July
2008 . Individual agricultural commodities show even more pronounced increases:
corn, wheat, rice and soybeans rose by 190,162, 318 and 246 percent,
respectively. Since July, food commodities prices began to fall. While this decline
comes as a relief, prices are likely to stay high in the foreseeable future. Available
evidence suggests that the decline in living standards of net consumers caused by
higher food prices outweighs the benefits accruing to poor net sellers in the majority
of countries that have been analyzed so far. The time to implement measures to
help the poor net consumers cope with higher food prices is now. However, too
many developing countries lack the instruments, administrative capacity and fiscal
space to implement safety nets fast enough and in the required scale. This is one
of the most pressing policy challenges that we face. For the poor who are net
sellers, governments should seize the opportunity to convert the short-run windfall
into longer-term gains. Multilateral financial institutions can play a key role in
providing financial resources to countries facing negative terms of trade shocks,
technical assistance in the design of safety nets and resources to add fiscal space
to countries to fund safety net programs. International organizations can also help
countries design the appropriate macroeconomic policy response. This will call for
greater flexibility in the menu of policy options traditionally deployed by the Bretton
Woods institutions.

The Center for Global Development is an independent, nonprofit policy research organization that is dedicated to reducing global poverty and inequality and to making globalization work for the poor. This paper was made possible in part by financial support from the William and Flora Hewlett Foundation.

Use and dissemination of this Working Paper is encouraged; however, reproduced copies may not be used for commercial purposes. Further usage is permitted under the terms of the Creative Commons License. The views expressed in this paper are those of the author and should not be attributed to the board of directors or funders of the Center for Global Development. 



\title{
Thought for Food: the Challenges of Coping with Soaring Food Prices ${ }^{1}$
}

\author{
Nora Lustig ${ }^{2}$ \\ October 30, 2008 \\ Abstract
}

\begin{abstract}
World food commodities prices increased 130 percent from January 2002 to July 2008. Individual agricultural commodities show even more pronounced increases: corn, wheat, rice and soybeans rose by 190, 162, 318 and 246 percent, respectively. Since July, food commodities prices began to fall. While this decline comes as a relief, prices are likely to stay high in the foreseeable future. Rising food prices are a cause of major concern because they bring significant and immediate setbacks for poverty reduction, social stability, inflation and a rulesbased trading system. There are three main drivers of rising food prices: long-term supply-side weaknesses, a change in demand due to the surge in the production of biofuels starting in 2004, and the combination of macroeconomic factors such as the depreciation of the dollar and lower interest rates in the United States with export-restricting policies on the part of developing countries since mid-2007. Higher world food commodities prices cause significant inflationary pressures for developing countries. One key policy dilemma is to what extent governments should allow the changes in world food commodities prices to be passed through to domestic prices. If the increase is a reflection of a global inflationary process, partially insulating domestic food prices may be the most adequate response. Many developing countries have chosen this path. The use of policy interventions that put a wedge between domestic and international prices exacerbates the price pressures in world markets for the affected commodities. Without a credible multilateral solution to large food price fluctuations, however, it is not surprising that countries pursue what is perceived as best for them even if the rest of the world is worse off as a result. A rules-based trading system should include safeguards and mechanisms which would make the protection of domestic consumers and producers from large-and recurrent-- food commodities price fluctuations (in either direction) orderly and legitimate. Available evidence suggests that the decline in living standards of net consumers caused by higher food prices outweighs the benefits accruing to poor net sellers in the majority of countries that have been analyzed so far. Implementing measures to help the poor net consumers cope with higher food prices are of the essence. However, too many developing countries lack the instruments, administrative capacity and fiscal space to implement safety nets fast enough and in the required scale. This is one of the most pressing policy challenges that we face. For the poor who are net sellers, governments should seize the opportunity to convert the short-run windfall into longer-term gains. Multilateral financial institutions can play a key role in providing financial resources to countries facing negative terms of trade shocks, technical assistance in the design of safety nets and resources to add fiscal space to countries to fund safety net programs. International organizations can also help countries design the appropriate macroeconomic policy response. This will call for greater flexibility in the menu of policy options traditionally deployed by the Bretton Woods institutions.
\end{abstract}

\section{Key Words: Food Prices, Poverty, Inflation, Multilateral Financial Institutions}

\footnotetext{
${ }^{1}$ This paper was prepared for the Center for Global Development. The paper benefited greatly from conversations with Nancy Birdsall, Guillermo Calvo, Rafael de Hoyos, Mario Dehesa, Alain de Janvry, Augusto de la Torre, Kemal Dervis, Kim Elliott, Jeffrey Frankel, Javier Garciadiego, Peter Hakim, Alain Ize, Steve Kamin, Danny Leipziger, Santiago Levy, Luis Felipe Lopez-Calva, Jorge Mariscal, Will Martin, Don Mitchell, Frances Stewart, Jaime Ros, Inder Ruprah, Peter Timmer and Joachim Von Braun. Needless to say, they do not bear any responsibility for any omissions, errors or mistakes. The author is very grateful to Maria Davalos for her excellent research assistantship and Mark Eisinger for his valuable editorial suggestions.

${ }^{2}$ Nora Lustig is a visiting fellow at the Center for Global Development and Shapiro Visiting Professor of International Affairs at the Elliott School of International Affairs, George Washington University.
} 
After three consecutive decades of decline ${ }^{3}$, world prices of food commodities have risen over the past five years at an alarming pace. (Figure 1) Between 2003 and 2008, world prices for meat and poultry nearly doubled, corn and wheat prices more than doubled, and butter and milk prices grew three times. An extreme example comes as the price of rice doubled in the lapse of four months! Since July 2008, food commodities prices began to fall. However, while this decline comes as a relief, food commodities prices are likely to stay high—significantly higher than at the end of the last decade-- in the foreseeable future.

Rising food prices are a cause of major concern because high food prices bring significant and immediate setbacks for poverty reduction, social stability, inflation and a rules-based trading system. Food prices are unique since food is unlike any other good. Food is not simply a source of pleasure. Food is essential for survival; it is the most basic of basic needs. Access to basic nutrition permits humans to live, work, reproduce and fend off disease. It should come as no surprise that the poor themselves list hunger and food insecurity as their core concerns. ${ }^{4}$ Food is special from the production point of view as well. It is the key ingredient in generating human energy, and human energy is essential to any, and all, economic activity. If food becomes permanently more expensive, long-term economic growth in the poorest countries could slow down.

What are the main causes of rising food prices? Are the increases in food commodities prices a change in their relative price (i.e., in their "true” relative scarcity) or part of a monetary phenomenon - that is, higher global inflation? To what extent is the increase in food commodities prices market-driven or policy induced? What are the short-term macroeconomic consequences of higher food commodities prices and how do they affect the living standards of the poor? What are the appropriate short-term policy responses on the part of developing countries? What policies should multilateral financial organizations support?

\footnotetext{
${ }^{3}$ The long-term decline observed in international prices of wheat and corn dates back earlier than the 1970s. The U.S. price of wheat in constant value in the 1980s was approximately half what it had been 100 years earlier (!). Less dramatic but not less significant, the decline in corn prices started after World War II. (Schuh, 1987, Figure 3-1, p.76).

${ }^{4}$ Narayan et al (2000), Chapter 2.
} 
There are three major drivers of rising world food commodities prices: long-term supply-side weaknesses, a change in demand due to the surge in the production of biofuels starting in 2004, and the combination of macroeconomic factors such as the depreciation of the dollar and lower interest rates in the United States with exportrestricting policies on the part of developing countries since mid-2007. In other words, the increase in food commodities prices is both a real and a monetary phenomenon and both market-driven and policy-induced.

Higher world food commodities prices cause macroeconomic imbalances for net food commodities importers and inflationary pressures for both net importers and net exporters. One key policy dilemma is to what extent governments should allow the changes in world food commodities prices to be passed through to domestic prices. This depends on the extent to which world food price increases reflect a real (and permanent) change in their opportunity cost or a monetary phenomenon. If it is a change in the relative price, domestic prices should be allowed to align themselves with international prices. But to the extent that the increase is part of a global inflationary process, allowing domestic relative prices to align themselves with international prices in full is not necessarily the most adequate policy response. As we shall see, many developing countries have chosen to (partially) insulate the domestic prices of food with a range of policy interventions.

Does poverty increase or fall with higher food prices? ${ }^{5}$ Since the poor include both net consumers and net sellers of food commodities, a change in their price in either direction will inevitably hurt some of the poor and benefit some of the poor at the same time. Available evidence suggests that among the poorest of the poor, the decline in living standards of net consumers caused by higher food prices outweighs the benefits accruing to net sellers in the majority of countries that have been analyzed so far. Implementing measures to help the poor net consumers cope with higher food prices are of the essence. However, as we shall see, too many developing countries lack the instruments, administrative capacity and fiscal space to implement safety nets fast

\footnotetext{
${ }^{5}$ The impact of higher food commodities prices on poverty has been the subject of some debate. Polaski (2008) and Aksoy and Isik-Dikmelik (2008)argue that many of the poor are net sellers of food commodities so that higher prices is a benefit to them while many others emphasize the negative net impact on the headcount and poverty gap ratios as illustrations of how higher food prices are hurting the poor (Ivanic and Martin, 2008; Wodon et al., 2008; Robles et al., 2008; CEPAL, 2008).
} 
enough and in the required scale. This is one of the most pressing policy challenges that we face. For the poor who are net sellers, on the other hand, governments should seize the opportunity to convert the short-run windfall into longer-term gains.

Multilateral financial institutions can play a key role in providing financial resources to allow countries that are facing negative terms of trade shocks (that is, net importers of commodities) to gradually (as opposed to abruptly) adjust to adverse external conditions. They can also provide technical assistance in the design of safety nets and add fiscal space to countries that need external resources to fund them. Finally, international organizations can help countries design the appropriate macroeconomic policy response. This will call for greater flexibility in the menu of policy options traditionally deployed by the Bretton Woods institutions. Such flexibility may have high pay-off not just for the countries themselves but for a rules-based trading system which has been weakened by myriad of unilateral decisions that restrict the flow of food commodities in the international markets.

The paper is organized as follows. In Section 1, I analyze the causes of rising food commodities prices; in particular, I discuss the role played by structural (declines in yield growth rates and the role played by corn- and oilseed-based biofuel production), idiosyncratic (e.g., bad weather) and macroeconomic factors (such as the depreciation of the dollar and the reduction in US interest rates after mid-June 2007). In Section 2, I look at how governments have been coping with the inflationary pressures and discuss under which circumstances putting a wedge between international and domestic prices may or may not be appropriate. I also examine the potential impact of higher food commodities prices on poverty and whether governments in developing countries are well equipped to deal with this impact. In Section 3, I present the main conclusions.

\section{Why did food prices rise?}

By every indicator, world food commodities prices have risen substantially. The IMF's index of internationally traded food commodities prices ${ }^{6}$ increased 130 percent

\footnotetext{
${ }^{6}$ A nominal dollar index of food commodity prices using global export value weights. It includes cereals, vegetable oils, meat, seafood, sugar, bananas, and oranges price indices.
} 
from January 2002 to July 2008. ${ }^{7}$ (Figure 2) Individual agricultural commodities show even more pronounced increases. For example, from January 2002 to July 2008 the international price of corn, wheat, rice and soybeans rose by 190, 162, 318 and 246 percent, respectively. (Figure 3$)^{8}$

Although rising food prices were previously noticed (and noted) ${ }^{9}$, it was not until the second half of 2007—and, in particular, in the first quarter of 2008 — that soaring food prices took center stage among the world's most pressing issues. ${ }^{10}$ There is of course reason for this lagged response. Although food prices have risen since 2002, the rate at which food prices increased accelerated from the second half of 2007 until June 2008. Between July 2007 and June 2008 prices rose by 42 percent; this is equivalent to a third of the increase observed from January 2002 onwards in 15 percent of the time. ${ }^{11}$

Why did food prices rise? Are the price increases policy-induced or market driven? Are they temporary or permanent? To what extent are food commodities price increases changes in their relative price or a monetary phenomenon-i.e., part of a global inflationary process--? As we shall see in this section, there are at least three

\footnotetext{
${ }^{7}$ In July 2008 prices started to fall. The increase between January 2002 and June 2008 equaled 130 percent.

${ }^{8}$ Data from IMF Primary Commodity Prices Database. Prices for corn refer to Maize (corn), U.S. No.2 Yellow, FOB Gulf of Mexico, U.S. price, US\$ per metric tone; for wheat to Wheat, No.1 Hard Red Winter, ordinary protein, FOB Gulf of Mexico, US\$ per metric tonne; for rice to Rice, 5 percent broken milled white rice, Thailand nominal price quote, US\$ per metric tonne; finally, for soybeans to Soybeans, U.S. soybeans, Chicago Soybean futures contract (first contract forward) No. 2 yellow and par, US\$ per metric tonne.

${ }^{9}$ See, for example, the World Development Report 2008 “Agriculture for Development” (World Bank, 2007), the OECD-FAO Agricultural Outlook 2007-2016 (OECD-FAO, 2007) and IFPRI’s Food Policy Report published in December 2007 (Von Braun, 2007).

${ }^{10}$ See, for example, the article published by the United Nations Secretary General in the Washington Post in March 2008 about food prices and its implications for food aid and development (Ban Ki-moon, 2008). Although not a comprehensive list, see also Abbott et al. (2008); Asian Development Bank (2008); Aksoy and Isik-Dikmelik (2008); Calvo (2008); CSIS (2008); CEPAL (2008); Collins (2008); CLAAF (2008); Dawe (2008); De Hoyos, Dessus and Herrera (2008); Elliot (2008); FAO (2008a); FAO (2008b); Frankel (2008a); Frankel (2008b) Frankel (2008c); IMF (2008); Ivanic and Martin (2008); Krichene (2008); Lipsky (2008); Lustig (2008a); Lustig (2008b); Mitchell (2008); Naylor and Falcon (2008); OECD (2008); ODS-UNDP (2008); Polaski (2008); RBLAC-UNDP (2008); Robles et al. (2008); Rojas-Suarez (2008); Rosegrant et al. (2008); Rosegrant (2008); Rosen et al. (2008); SELA (2008); Slayton and Timmer (2008); Subramanian (2008); Timmer (2008); UNCTAD (2008); United States Government Accountability Office (2008); Wodon et al. (2008); World Bank (2008a); World Bank (2008b); World Bank (2008c); World Bank (2008d); Von Braun (2008a); Von Braun (2008b); Von Braun (2008c); Zoellick (2008).

${ }^{11}$ Between October 2007 and June 2008, for example, they rose by 31 percent; this is equivalent to almost a quarter of the increase observed from January 2002 onwards in about a tenth of the time. A nominal dollar index of food commodity prices using global export value weights.
} 
distinct processes that explain the price increases starting in 2002: i. the reversal in the long-term trend of falling food commodity prices due to supply side constraints; ii. the increase in food commodity prices due to the structural shift in demand associated with the production of corn-based and oilseeds-based biofuels; and, iii. the acceleration-and overshooting-- of price increases since mid-2007 associated with expansionary monetary policy in the US and export-restricting government interventions in developing countries.

A wide range of factors have been identified as potentially significant to explain the phenomenon of rising food prices. (Table 1) Some are specific to the commodity markets while others are macroeconomic in nature. Some are market-driven while others are policy-induced, and some are both. Some take the form of short-run shocks while others are the result of structural changes.

Given the methodological difficulties involved, an attempt to estimate the exact contribution of each of these factors using econometrics or a comprehensive simulation model would be an impossible task. Instead, we will pursue an alternative approach: the process-tracing method which through the use of hypotheses, analytic explanations and a variety of empirical evidence-some more robust than other-- attempts to identify the intervening causal processes behind the recent episode of increases in food commodities prices. ${ }^{12}$ The presence of equifinality (the same outcome can be the result of alternative causal paths) makes the present explanations not conclusive enough for rigorous theory testing. However, the following analyses will allow us to find some causes more probable than others and help draw specific hypotheses for further scrutiny in the future.

\section{Reversal of the Long-term Trend of Falling Food Commodities Prices}

By and large, the performance of agriculture over the past twenty five years has been viewed as a success story. According to the World Development Report (2008), for example, “...[F]rom 1980 to 2004, the gross domestic product (GDP) of agriculture expanded globally by an average of 2.0 percent a year, more than the population growth of 1.6 percent a year. This growth, driven by increasing productivity, pushed down the

\footnotetext{
${ }^{12}$ For a discussion of the process-tracing method, see George and Bennett (2005).
} 
real price of grains in world markets by about 1.8 percent a year over the same period. ... Due to rising productivity, prices have been declining for cereals-especially for rice, the developing world's major food staple—and for traditional developing-world export products, such as cotton and coffee” ${ }^{\prime 13}$ Of course, low prices were also the consequence of agricultural support policies in the European Union and the United States. $^{14}$

However, at the turn of the century, this success story was coming to an end and standard models predicted that food prices would rise by 0.26 percent per year until 2030 and 0.82 percent per year from 2030 to $2050 .{ }^{15}$ What factors were behind this anticipated change? Contrary to the neo-Malthusian view that has characterized much of the public discussion, per capita consumption of cereals and meat was predicted to fall because of lower population growth as well as the per capita food consumption levels already attained in populous developing countries. ${ }^{16}$ The International Food Policy Research Institute (IFPRI) projections for demand to 2025-30 and 2050 predicted that growth in cereal consumption would slow from 1.9 percent a year during 1969-1999 to 1.3 percent a year during 2000-2030 and that growth in meat consumption would also slow from 2.9 percent to 1.7 percent a year. ${ }^{17}$

The main sources behind the expected change in price trends stemmed from supply-side constraints arising from land and water scarcity and slow technical progress. In the more densely populated areas of the world-primarily Asia-- the land frontier has been exhausted. In Latin America there is still room for land expansion but this often comes at the expense of tropical and subtropical forests. While in SubSaharan Africa there is great potential for land expansion, this would require large investments in infrastructure, human capital and agricultural extension. Water is likely to become increasingly scarce and irrigated agriculture would have to compete with the demand from larger and larger industrial sectors and urban centers. Climate change is likely to worsen the availability of arable land and water for agricultural use. Slowed R\&D spending cautions one to expect technological breakthroughs any time soon. The

\footnotetext{
${ }^{13}$ World Bank (2007), p. 51.

${ }^{14}$ For a discussion on this see, for example, IFPRI (2003).

${ }^{15}$ World Bank (2007), p. 62.

${ }^{16}$ This is due to an overall slowing of population growth and the already high levels of per capita food consumption attained in some of the more populous countries such as China. (World Bank, 2007, p. 62).

${ }^{17}$ World Bank (2007), p. 61. These are based on IFPRI’s “medium” scenario.
} 
supply-side constraints had already started to manifest themselves as a decline in the growth rates of yields of major cereal crops in developing countries.

Although models predicted prices to begin a rising trend, the orders of magnitude bear no resemblance with what happened to food prices in the past few years. As we saw above, from January 2002 to July 2008, the price index of internationally traded food commodities prices increased by 127 percent; about 20 percent per year or 100 times more than the predictions of the "business as usual" scenarios (!). The models are not meant to capture short-term fluctuations, but such a difference between predictions and actuality might be interpreted as a strong indicator that we are not living anymore in the "business as usual" world assumed by the models.

If future price increases were expected to be relatively moderate, what changed in such a fundamental way? Did demand for food consumption grow at unanticipated rates due to unprecedented global growth particularly in large emerging economies such as China and India? Did supply of food commodities grow at slower than expected rates due to low prices in the previous decade? Was supply systematically affected in a major way due to bad weather and disease? Were production costs much higher due to rising costs of energy-intensive inputs such as fertilizers and transportation? Was demand for food commodities significantly higher because of their use for biofuels production?

The Impact of Biofuels on Food Commodities Prices

Let us start by analyzing more closely what happened to demand and supply in the markets for grains and oilseeds from 2000 onwards. Since around 2000, the stocksto-use ratio for grains and vegetable oils began to fall and reached its lowest level in decades and in 2004 it started to decline for oilseeds. (Figure 4) This is a clear sign that demand was outpacing supply. But was it due to a decline in harvested area, lower yields due to bad weather and disease, rising demand for food consumption or an increase in demand for industrial—-that is, biofuels—use?

Table 2 presents a summary of trends in harvested area, yields, food consumption, industrial use and stocks-to-use ratios for corn, rice, wheat and oilseeds. Evidence shows that there was a steady decline in harvested area (for corn and wheat in 
particular) at the beginning of the decade, a likely result of low prices in the past. ${ }^{18}$ Bad weather had a negative impact on yields and, on specific years, the yields fell below trend for wheat and rice in particular. However, the harvested area for corn, for example, rose sharply in response to higher prices and by mid-decade there were record global crops for corn and oilseeds. These trends seem to indicate that supply (harvested area) was gradually responding to incentives and bad weather was neither generalized nor persistent. Between 2000 and 2007, for all grains, harvested area grew at 0.4 percent and yield grew at 1.3 percent per year, which combined, as we shall see below, should have been enough to cover growth in demand for food consumption purposes. ${ }^{19}$

On the demand side, consumption for food (including animal feed) of corn, wheat and rice was for the most part on trend. Contrary to what is often mentioned in the press, there were no surges in consumption on the part of China or India (or by developing countries in the aggregate) for corn, wheat or rice. The exception is oilseeds (soybeans in particular) for which the demand from China increased above trend. Demand for food consumption (including animal feed) for all grains grew at 1.7 percent per year from 2000 to $2007 .{ }^{20}$ Hence, excluding the demand for industrial use (biofuels), supply and demand grew at the same pace.

In contrast, after legislation on mandates, tariffs, and subsidies was passed in the $\mathrm{EU}$ and the $\mathrm{US}^{21}$, the demand for corn and vegetable oils for industrial use (biofuels) rose above trend and at an increasing rate. (Figures 5 and Table 3) The use of corn for ethanol grew rapidly from 2004 to 2007. Feed use of maize, which accounts for 65 percent of global maize use, grew by only 1.5 percent per year from 2004 to 2007 while ethanol use grew by 36 percent per year and used 70 percent of the increase in global corn production. $^{22}$ Industrial use of vegetable oils (which includes biodiesel) grew by 11 percent per annum from 2004 to 2007, compared with 3 percent per annum for food use. $^{23}$ It is estimated that about one-third of the increase in consumption from 2004 to 2007 was due to biodiesel. In Figure 6 we can observe how price increases of corn and

\footnotetext{
${ }^{18}$ Timmer (2008) estimates that lower prices in the previous decade explain around 53 percent of the increase. On the harvested area and yield by crop see, for example, Abbott et al. (2008). Also, see Naylor and Falcon (2008).

${ }^{19}$ Mitchell (2008).

${ }^{20}$ Ibid.

${ }^{21}$ Legislation was passed in 2005 and implemented in 2006.

${ }^{22}$ Ibid.

${ }^{23}$ Author's calculations based on data from the PSD Database, USDA.
} 
soybeans accelerated after the demand for corn-based ethanol experienced its rapid increase.

In quantitative terms, the contribution of biofuels to the rise in food commodities prices has been estimated or calculated using different time periods and prices, different coverage of food products, and different methodologies. ${ }^{24}$ The general conclusion that emerges from these exercises is that the contribution of the expansion of biofuels to observed price increases is quantitatively significant. Collins (2008) estimated that around 60 percent of the increase in maize prices from 2006 to 2008 may have been due to the increase in maize used in ethanol.”25 Mitchell (2008) concludes that “... the combination of higher energy prices and related increases in fertilizer prices and transport costs, and dollar weakness ... explain 25-30 percent of the total price increase, and most of the remaining 70-75 percent increase in food commodities prices was due to biofuels and the related consequences of low grain stocks, large land use shifts, speculative activity and export bans.”26 Using a general equilibrium model, Rosegrant, et al. (2008) estimated the impact of the acceleration in biofuel production on weighted cereal prices from 2000 to 2007 to be 30 percent in real terms. ${ }^{27}$

How much of the increase in food commodities prices is caused by policyinduced increases in demand for biofuels as opposed to market forces such as higher gasoline prices (derived from higher oil prices)? According to McPhail and Babcock (2008) eliminating federal ${ }^{28}$ tax credits (for blending ethanol in gas) and tariffs-and, to a much lesser extent, mandates - in the United States would reduce ethanol production by 18.6 percent and the price of corn would decline by 14.5 percent. While significant, this leaves a large portion of the increase unexplained. What other factors made the production of biofuels profitable?

\footnotetext{
${ }^{24}$ For example, computable general equilibrium models (Rosegrant et al., 2008) or partial equilibrium analysis (Collins, 2008) or estimated as an accounting residual (Mitchell, 2008).

${ }^{25}$ Mitchell (2008), p. 4.

${ }^{26}$ Ibid., p. 16.

${ }^{27}$ Also, in the short-run, the IMF estimated that the increased demand for biofuels accounted for 70 percent of the increase in maize prices and 40 percent of the increase in soybean prices (Lipsky, May 8, 2008). A recent OECD report (OECD, 2008) calculates that "current biofuel support measures are estimated to increase average wheat, maize and vegetable oil prices by about $5 \%, 7 \%$ and $19 \%$, respectively, in the medium term" (p.9).

${ }^{28}$ In addition to policies at the federal level, there are mandates and other policies at the state level which also affect ethanol and biodiesel production. (Elliott, 2008)
} 
One obvious candidate is higher gasoline prices. If gasoline prices are sufficiently high, the production of biofuels may be profitable even without the mandates, tax credits and the like. There is a gas price for which the mandates and subsidies become unnecessary in order to make the production of biofuels financially profitable. According to McPhail and Babcock (2008) ${ }^{29}$, even if government support policies at the federal level are eliminated, if gas prices were to stay at 3 dollars per gallon or higher, ethanol production would rise from the current levels of 6.5 billion gallons to 14 billion gallons and corn price would stay at 4 dollars a bushel $^{30}$ (until recently prices were around 7 dollars a bushel). In fact, as Elliott (2008) shows the mandated levels required by the Energy Policy Act of $2005^{31}$ in the United States were apparently non-binding. (Figure 7$)^{32}$

Markets were undoubtedly "stressed” before the expansion of biofuels production. ${ }^{33}$ However, in the absence of the rise in demand for biofuels, the price increases would have been more moderate, especially for corn. In particular, one would have expected the price increases to subside in 2004/05 when there were record global harvests in corn and oilseeds. Instead, price increases for corn accelerated. Between January 2002 and January 2004, for example, the monthly rate of growth for corn prices was 1 percent on average while between January 2005 and June 2007 the monthly rate of growth rose to 2.4 percent on average. The surge in the demand for corn to be used as inputs in the production of corn-based biofuels is a natural "suspect" because of the additional pressure this placed on markets that were already tight. It is not just the increase in "physical" demand that matters here (that is, a horizontal shift in the demand curve due, for example, to political mandates). It is also the fact that as oil prices rose, consumers were willing to pay higher prices for biofuels and producers were able to ask

\footnotetext{
${ }^{29}$ http://www.econ.iastate.edu/research/webpapers/paper_12943.pdf.

${ }^{30}$ A bushel is equal to 56 pounds.

${ }^{31}$ Signed into law (Public Law 109-58) by President Bush on August $8^{\text {th }}$ of 2005.

32 This is not proof that the same increase in biofuels production would have existed without government support. It is still possible that without the tax credits or protection from imports, the production of biofuels at those same prices would have been lower. According to Naylor and Falcon (2008), in the absence of government support policies, oil prices would have to be high enough and corn prices low enough to make ethanol production profitable at 65 percent the price of gas . “...[E]thanol has only about two-thirds the energy of gasoline. In other words, rational consumers would pay only about $65 \%$ of the price of gasoline for their ethanol, since their cars would go only about $65 \%$ as far on a tank of fuel. Since ethanol must be shipped and stored separately, substantial new infrastructure would be needed to make it a large-scale choice for fuel, and autos would require so-called "flex" technology to use fuel containing high percentages of ethanol."

${ }^{33}$ For an estimate of the order of magnitude of the impact of past prices on current prices see Timmer (2008).
} 
for higher prices (that is, a vertical shift in the demand and supply curves). The global agricultural markets are highly interconnected. There are complex interactions between corn and oilseeds and other crops such as rice or wheat through substitution on the demand or supply side. ${ }^{34}$ If the price of the former goes up, through adjustments in behavior on the demand and supply side and arbitrage conditions, the other prices will follow suit. ${ }^{35}$

The fact that food commodities have become a profitable alternative for the production of "non-human" energy has important implications. ${ }^{36}$ In contrast to food being used for consumption purposes whose income-elasticity is below unity (that is, the rate of increase in per capita food consumption falls as income per capita grows or Engel's Law), the income elasticity for food commodities used to produce nonhuman energy could equal unity or more. ${ }^{37}$ This turn of events significantly alters the forces at play in food commodities markets and--depending on what happens to oil prices, biofuels subsidies and mandates and research on the agricultural frontier--food could

\footnotetext{
${ }^{34}$ For example, in the US corn displaced soybeans in planted area and in the EU oilseeds displaced wheat. (Mitchell, 2008)

${ }^{35}$ For example, in 2007 harvested area for corn in the US rose by 23 percent “... in response to high maize prices and rapid demand growth for maize for ethanol production. This expansion resulted in a 16 percent decline in soybean area (Figure 6) which reduced soybean production and contributed to a 75 percent rise in soybean prices between April 2007 and April 2008.” (Mitchell, 2008, p. 10) And, Naylor and Falcon (2008) described the interaction between ethanol, corn prices, soybean prices and wheat prices in the following account: “... Ethanol, while the beginning of the corn story, is far from the end of it. Corn's other linkages to soybeans, wheat, and meat illustrate why it is the keystone in the food system. Midwestern farmers who produced the record corn crop in 2007 made a series of acreage decisions that reverberated around the world. Corn area was up more than 15 million acres in 2007 in response to rising expected prices. That increase came mainly at the expense of soybeans that saw a decline of 12 million aces (16\% of total soybean acreage). Part of the decreased global soybean production in the U.S. was taken up by Brazil, the other major soybean exporter. But, the world's production of soybeans declined in 2007, just at a time when three of the four largest counties in the world—China, India, and Indonesiaregistered very strong growth in their economies. China imported an incredible $34 \mathrm{mmt}$ of soybeans (45\% of total world trade), which it used to produce soybean meal for some of its 600 million pigs and its large and rapidly growing aquaculture sector, and vegetable oil for its rapidly growing urban population. In India and Indonesia, the story focused less on meat and more on vegetable oil. India, for example, is one of the largest users and importers of cooking oils in the world. ... Wheat prices also went off the charts in 2008 as a consequence of wheat's feed relationship with corn, and partly because of two factors specific to wheat production. Corn and wheat are both used by the animal-feed industry, and in some years, one quarter of the wheat crop is fed directly to animals. As the cost of using corn for feed rose in 2007, producers of livestock products looked to other grains. Since the feed value of wheat is slightly higher than corn, it is not surprising that their prices moved in tandem as producers moved among markets to find the cheapest rations. More generally, at a wheat price of 1.1 times that of corn, livestock producers are generally indifferent to which of the two grains they use.” The linkages soon reach the breakfast table. Higher corn prices, for example, have made products whose production relies on grainbased feed, such as milk and eggs, more expensive.

${ }^{36}$ By this we mean the use of food commodities to produce energy for cars and machines.

${ }^{37}$ The long-run income elasticity of energy and oil has been estimated at approximately 1.0 for the nonOECD countries (Gately and Huntington, 2001).
} 
become permanently more expensive in a nontrivial way. In addition, the new link between the prices of food commodities and the prices of energy commodities makes the prices of the former much more sensitive to the economic cycle and macroeconomic policies. The impact of expansionary macroeconomic policies or of periods of aggregate global growth above capacity (overheating) on food commodities prices will be larger than it used to.

The main issue here is that with this structural shift in the demand for food commodities (corn and oilseeds in particular), other things equal, the rise in their real prices will continue well into the future. OECD (2008) estimates various policy scenarios for biofuel production and states that "with full implementation of the recently enacted US Energy Independence and Security Act and the currently proposed new EU Directive for Renewable Energy, close to 20\% of global vegetable oil production and more than $13 \%$ of world coarse grain output could shift to biofuels production”. ${ }^{38}$ Von Braun (2008) finds that with the current growth path of biofuel production, i.e. with the actual expansion plans for biofuels, oilseeds and corn prices would increase by 18 and 26 percent, respectively, by 2020. In contrast, the "business as usual”-that is, without biofuels--scenario mentioned above predicted an increase in food commodities prices of .26 percent per year or around 5 percent by 2020 .

The Acceleration in Food Price Increases since mid-2007: Macroeconomic Factors and Policy Reactions in the Developing World

The increase in prices of food commodities-along with other commoditiesaccelerated from mid-2007 up until mid-2008 when they began to fall. Between October 2007 and June 2008, for example, they rose by 31 percent: that is, almost a quarter of the increase since 2002 took place in about a tenth of the time. Was this acceleration driven by the same forces as discussed above? In other words, did they result from the strong nonlinearities or discontinuities that characterize agricultural markets when the stocks-to-use ratios are low? Were export restrictions and other defensive policies by developing countries a major driver? What role did

\footnotetext{
${ }^{38}$ The EU directives were revised so their impact needs to be re-estimated.
} 
macroeconomic factors -- such as the depreciation of the dollar and lower interest rates in the US--play?

\section{Export Restrictions}

When stocks are low in markets with low demand and supply price elasticities, very small changes in demand or supply (or expected demand or supply) can have large effects on prices. Clearly during this period there were new incidents that could have had strong effects on expected demand and supply and consequently affected prices. In particular, administrative decisions to ban or restrict exports and put bids on purchases in some developing countries exacerbated the stress in what were already tight markets.

These undesirable dynamics seems to have impacted in particular the international price of rice. ${ }^{39}$ In Figure 8 one can observe how the acceleration in the price increases of rice coincided with the time in which some key countries introduced administrative measures that affected the supply or demand. It apparently started with the decision by India's food authority to place restrictions on rice exports in October 2007. In the face of rising world wheat prices, the fear of disruptions in the supply chain and the prospect of poor harvests in the country, the Indian government decided to guarantee supplies of rice for its public distribution program and placed bans on exports of non-basmati varieties of rice, wheat, and wheat flour. In addition, the Indian Government restricted wheat imports for the purpose of disease control. ${ }^{40}$

The Indian Government's decision triggered an immediate increase in the price of rice in the international markets which went from 300 dollars to 400 dollars per ton. The price continued its upward acceleration, and shortly afterwards Vietnam, China, Cambodia, Indonesia and Egypt followed suit in imposing restrictions on rice exports. Meanwhile, the Philippines (the largest importer of rice in the world) began to place bids for imports at any price in April 2008. At this point, the price of rice rose to $\$ 850 /$ ton and soon exceeded \$1000/ton in May as additional countries placed bids. For several weeks, panic reigned to the point that even large US retail food chains put limits

\footnotetext{
39 See Slayton and Timmer (2008), Naylor and Falcon (2008).

${ }^{40}$ Slayton and Timmer (2008) were among the first to describe this process. Also, see Naylor and Falcon (2008).
} 
on the number of bags of rice consumers could purchase. These high prices left some of the poorest countries (in Sub-Saharan Africa and Bangladesh) without the ability to afford rice imports. In Africa, the domino effect on other prices did not wait; with rice and other imported cereals in short supply, the price of locally grown crops such as millet and sorghum rose. ${ }^{41}$

Governments that introduced unilateral export restrictions or subsidized imports have been criticized because their actions drove already high international food prices even higher. However, these measures were taken in the context of extraordinary circumstances prevailing in the world food commodities markets. As we saw above, a significant portion of the rise in the prices of some commodities is due to the rapid increase in the production of corn- and oilseed-based biofuels and part of this increase is explained by subsidies for biofuels production in the European Union and the United States. Thus, the "moral imperative” cannot be used as a reason to persuade governments in developing countries to give up defensive policies if the rich countries are not willing to contribute with their share (i.e., by phasing out the policies in support to biofuels). Second, the threat to political and social stability derived from higher food prices is all too real for governments to ignore in the name of a "global common good." In the absence of a coordinated response such as international stocks that can be deployed to avoid shortages and price spikes, it is understandable that countries decide to concentrate on protecting their own.

In addition, as we shall see below, in the last few months the uncertainty surrounding the short-term "equilibrium” level of food commodities prices has been heightened by the fact that it is not entirely clear to what extent "transitory" macroeconomic factors - such as the depreciation of the dollar and lower interest rates-and speculation were affecting the relative prices of all commodities (including food commodities). For instance, to what extent commodities price increases were reflecting the relative scarcity of commodities in a very tight market? Or, instead, were part of a global inflationary process with commodities taking the lead?

\footnotetext{
${ }^{41}$ Naylor and Falcon (2008) and the article by Fleshman (2008).
} 
This may be a good place to bring into the discussion the impact of macroeconomic factors in explaining the increase in food commodities prices. In addition to above trend global growth, there are two other macroeconomic variables that-in theory-- can affect commodity prices: exchange rates (in particular, the value of the dollar vis-à-vis other currencies) and interest rates (in particular, US interest rates). At the heart of the discussion of the role of macroeconomic factors is whether commodities price increases indicate a change in relative prices or whether they are part of a monetary phenomenon: that is, global inflation induced by US monetary policy. This distinction is important because the correct mix of domestic policy responses will be different depending on the case.

\section{$\underline{\text { The Depreciation of the Dollar }}$}

There is evidence that the cycle of the dollar against major currencies is related to the cycle of the dollar price of commodities. According to Mundell (2002): “[A] casual reading of the statistics suggests that this relationship is quite close. Thus the index of non-oil dollar commodities tripled in the 1970s when the dollar was depreciating sharply relative to the SDR; it then fell by more than 20 per cent from 1980 to 1986 when the dollar was soaring; then it rose by 50 per cent from 1986 to 1995 when the dollar was again depreciating; and it has fallen by 30 per cent since 1995 when the dollar has been appreciating. There is therefore a very pronounced association of the cycle of the dollar against other major currencies (as measured by the SDR) with the cycle of dollar commodity prices.”

This inverse relationship continued in the 2000s: as the dollar depreciated, commodity prices went up. (Figure 9) As shown in Figure 10, however, commodity prices rose in all major currencies. This is an indication that factors other than the depreciation of the dollar played a significant role. However, it is quite possible that the depreciation of the dollar may have affected the short-run dynamics of commodity prices because of higher demand stemming from the countries whose currencies appreciated vis-à-vis the dollar.

The relationship between exchange rates and the prices of commodities in the current international monetary regime-characterized by multiple exchange rates-is complex and not fully understood. That is why at present we rely on empirical 
regularities as a proxy. Available estimates put the elasticity between 0.5 and 1.0. ${ }^{42}$ Using the mid-point of these elasticities and the trade-weighted depreciation of the dollar, Mitchell (2008) argues that the contribution of dollar weakness to the increase in commodity prices between January 2000 and June 2008 could be of the order of 20 percent (.75 times 26 percent). ${ }^{43}$ However, the selection of the mid-point is as good as any other.

In a world of multiple exchange rates and in the presence of an unstable dollar, should the dollar be the numeraire to measure the "true" opportunity cost of commodities? Perhaps not and much less so in the short-run. This might be a good reason why governments may resist passing the increase in dollar international prices through to domestic prices and instead choose to resort to measures such as price controls and export bans. However, given that commodity prices rose in all major currencies, not passing through to domestic prices at least part of the increase may cause more problems to countries down the road.

The Sub-Prime Mortgage Crisis, Interest Rates and the Commodity Price Rise Acceleration

Following the onset of the sub-prime crisis in mid-2007, there was a remarkable acceleration in commodity price increases. (Figure 11) Could the two events be linked? Frankel ( 2008b) argues that the fact that commodity prices have risen across the board calls for some macroeconomic explanation. For a while, the most popular macro explanation was rapid growth in the world economy. However, since mid-2007 (and until mid-2008) price rises accelerated even though the global economy has been

\footnotetext{
${ }^{42}$ Gilbert (1989) and Baffes (1997).

${ }^{43}$ We must bear in mind, also, that causality runs both ways. A productivity boost generated by allpurpose technology such as the IT "revolution" would result in an appreciation of the currency of the leader in the use of such technology and a reduction of commodity prices. On the contrary, an exogenous increase in commodity prices will put downward pressure (i.e., towards depreciation) on the currency of importing countries. If part of the increase in commodity prices (food and nonfood) is determined by exogenous factors (such as rapid growth in China), this would have put downward pressure on the dollar. However, this would have been countered by the rise in prices of commodities where the US is a major exporter. But because the US is a net importer of commodities, it suffered a decline in its terms of trade of about 7.5 percent between 2002 and 2007.
} 
slowing down. ${ }^{44}$ According to Frankel (2006, 2008), Calvo (2008) and others, one of the explanations may be the Federal Reserve's decision to lower interest rates since mid-2007. Lower interest rates increase the demand for or reduce the supply of storable commodities through a variety of channels: by decreasing the incentive for pumping oil, mining gold, logging forests, culling cattle, etc. today rather than tomorrow; by increasing the desire to hold inventories; and, by encouraging investors (or speculators if you wish) to shift out of Treasury Bills and into other assets such as foreign currencies, emerging market stocks, other securities, and commodities-including food commodities.

The mechanism proposed in Frankel's model is the following. Commodity prices are determined by a number of factors including investors' asset portfolio decisions. The decision whether to hold a commodity for another period (on the ground, in the trees or in the form of inventories) or to sell it at today's price, deposit the proceeds and earn interest, depends on the interest rate and the expectations about prices in the future. Thus, through arbitrage conditions, the relative price of a commodity (visa-vis its long-term equilibrium) is inversely related to the real interest rate. The mechanism at play is the following. When interest rates are low-such as in the present scenario-- money flows out of interest-bearing instruments and into foreign currencies, emerging market stocks, other securities, and commodities_-including food commodities. This portfolio shift drives the prices of these assets higher and higher until they reach a level where people perceive that they lie "sufficiently" above their future long-run equilibrium level. Monetary policy causes real commodity prices to rise initially (they increase more than proportionately than the increase in money supply, for example) because other prices are "sticky" (or, in other words, they rise at a slower speed). Because of the different speeds of price adjustments and arbitrage conditions regarding price expectations and interest rates, commodity prices (and other the prices of other assets) overshoot in real (and often in monetary) terms. ${ }^{45}$

\footnotetext{
44 The IMF reduced predicted growth rates for the world in 2008 from 5.2 percent in July 2007 to 4.1 percent in January 2008 (IMF World Economic Outlook Updates for July 2007 and January 2008). The WEO Update for July 2008 has kept the 4.1 percent projection for world output growth..

45 There has been a lot of debate about whether speculation contributed to the acceleration of commodity prices. If one considers "speculation" any decision that is based on the expectations of the behavior of prices in the future, the process described above could be included as part of speculative activities.
} 
Frankel (2006) provides econometric evidence in support of the inverse relationship between commodity prices and real interest rates in the US dating back to the 1950s which is generally robust. ${ }^{46}$ Casual observation (Figures 11 and 12) shows that the decisions to lower interest rates by the Federal Reserve in mid-2007 were followed by an acceleration in the price increases. In Frankel’s own words: “...events since August 2007 provide a further data point. As economic growth has slowed sharply, both in the US and globally, the Fed has reduced interest rates, both nominal and real. Firms and investors have responded by shifting into commodities, not out. This is why commodity prices have resumed their upward march over the last six months, rather than reversing it.” ${ }^{47}$ One could also add that the relatively rapid fall in all commodity prices between July and August 2008 contributes to yet another data point in the theory by giving more credibility to the notion that there was "overshooting" in the behavior of the prices of commodities. ${ }^{48}$ Spot prices for food (and practically all) commodities fluctuated sharply since January 2008. In the case of food commodities, for example, the price of wheat went from \$370 to \$440 from January to March to then fall to \$329 in May and the price of rice went from \$394 in January to \$1009 in May and dropped to \$799 in July and \$737 in August. Similarly, the price of corn started at a level of \$207 in January, it peaked in June at \$287 (a 39\% increase) and dropped 7 percent in July and even further in August back to March 2008 levels (\$235). 49

The role of expansionary monetary policies in explaining rising commodity prices in the aftermath of the sub-prime crisis has also been suggested by the Latin American Shadow Financial Regulatory Committee (CLAAF). ${ }^{50}$ According to the Committee, “...[W]hile a monetary explanation focuses essentially on absolute price changes, it may also accommodate the possibility of a transitory increase in relative

\footnotetext{
${ }^{46}$ Frankel (2006)

${ }^{47}$ Frankel (2008b).

${ }^{48}$ Even if it is demonstrated that the Federal Reserve's policies contributed to price rise acceleration, this should not be interpreted as a criticism to these policies. Given the all too real prospects of a systemic financial meltdown, the Fed was probably right in lowering interest rates even at the risk of fueling inflation.

${ }^{49}$ Data is from the IMF Primary Commodities Database. Prices are in US\$ per metric tonne. For wheat, prices are for Wheat, No.1 Hard Red Winter, ordinary protein, FOB Gulf of Mexico. For rice, prices are for Rice, 5 percent broken milled white rice, Thailand nominal price quote. Maize (corn), U.S. No.2 Yellow, FOB Gulf of Mexico, U.S. price, US\$ per metric tonne. Soybeans, U.S. soybeans, Chicago Soybean futures contract (first contract forward) No. 2 yellow and par, US\$ per metric tonne.

${ }^{50}$ CLAAF (2008).
} 
prices. More precisely, an increase in inflation, in its initial stages, tends to manifest itself as a non uniform process. In particular, commodity prices react faster than wages and prices of domestically produced services. Therefore, in the short run, a rise in the rate of inflation will bring about an increase in the relative price of commodities vis-àvis less flexible prices. It is worth noting that the monetary explanation implies that, in the long run, there will be no major relative price change. Thus, the entire episode might resemble a price bubble. Furthermore, the increase in commodity prices becomes a leading indicator of future generalized inflation." ${ }^{51}$ This process relies entirely on the assumption that prices adjust at different speeds, an assumption that empirical evidence suggests it is valid.

The importance of expansionary monetary policy as a cause of the acceleration of the price increases has been dismissed because if that were the case, one would observe an increase in stocks of commodities_-including food commodities-- and available evidence does not seem to show this. ${ }^{52}$ However, in the case of certain commodities such as oil or metals, stocks can be accumulated in "invisible" ways: by drilling or mining less. In the case of agricultural commodities, this option does not really exist because one cannot accumulate them by simply not harvesting a crop. But, as Calvo (2008) has argued, in the face of highly inelastic demand, the desired level of stocks may increase, but given the short run inelastic nature of supply, this may express itself by rising prices rather than higher stocks. (Note, by the way, that government interventions to restrict exports and expand subsidies have contributed to the inelasticity of supply and demand). Furthermore, it is probably naïve to think that stocks accumulated by sovereign governments are public knowledge in full. ${ }^{53}$ Finally, because of the recently created link between food commodities and fossil fuels through the biofuels nexus, part of the impact of lower interest rates on food commodities prices

\footnotetext{
${ }^{51}$ Also, see Rojas-Suarez (2008).

52 See, for example, Krugman (2008).

${ }^{53}$ In addition, in the case of agricultural commodities in particular, accumulation of stocks may be "invisible” because it is done by millions of consumers buying additional amounts which although small individually, can add up and put upward pressure on prices. If, for example, if we take half of the population of India, China, Indonesia and Bangladesh (a total of 1,428,658,500 persons, WEO data) and assume an increase in the amount of rice bought by consumers of 10 kilos per year per person, this would result in an increase in demand in the order of 14,286,585,000 kilos or 14,286,585 tons. With world rice production at 430.72 million tons in 2008 (USDA) this represents 3.3\% of world production or $5 \%$ of the production in these four countries (which in 2008/2009 is estimated at 292 million tons, USDA). In addition, export restrictions imposed by governments are tantamount to a form of speculation because they also restrict supply available in world markets.
} 
may be indirect (that is, there is no need to observe an accumulation of their inventories). ${ }^{54}$

One important aspect to bear in mind is that the explanations of the acceleration in commodity price increases based on fundamentals vs. monetary factors, though clearly distinct, are not mutually exclusive. The explanation which emphasizes the workings of physical demand and supply for commodities, considers inflation a consequence of these persistent relative price changes. In contrast, for the monetary explanation, the increase in the relative price of commodities is partly endogenous: a consequence of expansionary monetary policy. But both may be and are likely to have been at play. This is an area that deserves further research.

The reason why it is of such importance to know to what extent the price rise acceleration since mid-2007 is determined by fundamentals or is a monetary phenomenon is because the appropriate policy response differs depending on the case. If price increases are a reflection of a "true" change in their relative price, governments should allow the increase to be reflected in domestic prices. To the extent that the price changes are the result of global inflationary pressures associated with lower US interest rates it might be sensible policy for governments to try to partially decouple domestic prices from the behavior of international prices. However, as we will discuss in more detail below, this response should not be overdone. In addition to the harm done to others, not allowing higher international prices to be passed through to domestic prices may also result in serious distortions in producers and consumers' response. It can also defer and worsen inflationary pressures, exacerbate fiscal imbalances and channel large amounts of scarce government resources to the non-poor. ${ }^{55}$

\footnotetext{
${ }^{54}$ However, correlation is not proof of causality. The spike in prices could also be explained by the nonlinearities present in tight commodity markets which were subject to additional shocks such as the administrative decisions mentioned above (export bans, export taxes, etc.). And the recent fall could be explained by the expected downward pressure on prices resulting from a slowdown in global growth. In addition, the inverse relation between commodity prices and interest rates does not always hold empirically.

55 Another factor which has been mentioned to explain the acceleration in commodity price increases since mid-2007 is speculation in financial markets and the rise in the participation of index funds. So far, the evidence does not seem to support the idea that they have played a fundamental role in explaining the rise; they have contributed to higher volatility in the prices though.
} 


\section{The Impact of Rising Food Prices on Inflation and Poverty}

The rapid increase in food commodities prices is having a significant impact on poverty reduction and developing countries' macroeconomic conditions. Rising food prices increase poverty for millions of poor (and near-poor) people throughout the developing word. If high food prices persist, there could be irreversible damage to the human capital of the poor and a significant reversal in the progress made towards achieving the Millennium Development Goals. The damage to human capital, if large and persistent enough, could in turn have a negative impact on long-term growth particularly in the poorest countries.

Rising food prices, however, not only cause poverty to go up. They also reduce poverty for millions of poor farmers. However, this should not be a source of comfort. While it is important to point out that some of the poor gain from higher food prices, netting the impact is not the right approach: one of the worst types of redistribution is one in which some of the poor benefit at the expense of others who are also poor. Food insecurity is very painful to the poor who are hurt by higher food prices. The thousands of testimonials gathered in the World Bank's volume Voices of the Poor portray the sense of deprivation that lack of food brings to the poor. In country after country, the poor distinguish themselves from the non-poor because there is hunger in their households. ${ }^{56}$ The poor forego meals on a regular basis and eat nutritionally inadequate diets. For the poor lack of access to food means distress at being unable to feed their children, anxiety from not knowing where the next meal will come from, and insecurity from not being able to work at full potential because of weakness and disease.

Rising food commodities prices pose significant macroeconomic challenges and policy dilemmas to developing countries. Both commodity exporters and commodity importers ${ }^{57}$ must grapple with inflationary pressures. And both face the dilemma of how much of the food commodities world price increases should be passed through to domestic consumers.

\footnotetext{
${ }^{56}$ Narayan et al. (2000).

${ }^{57}$ The terms “commodity exporters (importers)" actually refer to net commodity exporters (importers): i.e., those countries for which the revenues generated by commodity exports exceed (are below) the amount paid for commodity imports.
} 
High food prices are a source of social unrest and many countries have faced food protests and riots, some of them quite violent (Figure 13). Persistent high food prices could also become a contributing factor to new conflicts or relapses in postconflict countries. The more vulnerable cases are likely to be those in which food production or marketing, or the pain of higher food prices, is concentrated in certain geographic areas and/or in certain ethnic or religious groups. ${ }^{58}$ High food prices can also exacerbate the devastating consequences of conflict by undermining access to food for the poor and vulnerable. And as the World Food Program has demonstrated, they have created severe budgetary difficulties for food aid programs and made planning for food relief excruciatingly difficult.

Faced with falling living standards, inflationary pressures, food insecurity and the threat (or reality) of social unrest, governments in developing countries have been resorting to measures that have exacerbated the upward pressure on world food commodities prices and weakened a rules-based international trading system. Soaring food commodities prices have pushed governments to intervene in markets sometimes in often inefficient and beggar-thy-neighbor ways. To cope with their repercussions, governments are using price controls, general (as opposed to targeted) subsidies and export restrictions or outright bans; and, net importers of food are debating whether they should re-instate agricultural support policies and trade barriers eliminated during the structural adjustment programs of the 1980s and 1990s in order to become more selfreliant in food production. This process has significantly undermined a rules-based trading system. Even the recent collapse of the Doha Trade Round negotiations was due in part to the fall-out of high food prices. As food security returns to the political agenda, many developing countries want to protect their agricultural sector from surges in external competition through special safeguards, subsidies or trade barriers. As long as the multilateral system does not address how to eliminate the policy-induced sources of higher food prices (such as government support for corn- and oilseeds-based biofuels production on the part of rich countries) and reduce price fluctuations associated with idiosyncratic shocks or global inflationary pressures, it should come as no surprise that

\footnotetext{
${ }^{58}$ Historians have documented how food conflicts and riots arise in situations where a group with enough purchasing power can attract food from regions which grow it even if it is at the expense of those with weak or lost purchasing power who are left without adequate access to food (Tilly,1983; Tilly, 1975) Current research, however, has focused on conflict as a cause of food insecurity (Nafziger, Stewart and Väyrynen, 2000; Stewart, Fitzgerald and Associates, 2001).
} 
developing countries will choose to protect their own interests even if it is at the expense of others.

\section{Rising Food Prices and Inflation}

Rising food commodities prices pose significant macroeconomic challenges and policy dilemmas to developing countries. This is particularly so because it is not just food commodities which have been rising in price; all commodities have, including energy prices. Commodity exporters ${ }^{59}$ have been experiencing a boom and fiscal revenues have risen. However, the number of countries in this category is smaller than those hurt by higher commodity prices. As shown in Figure 14, the change in terms of trade for food and fuel combined is positive for 29 countries and negative for 87. Moreover, the question remains whether countries that benefit from higher food and fuel prices have been able to transform the windfall into sustainable growth or continue to be vulnerable to the "natural resource curse."60 As for commodity importers, until mid-2007 they were partially insulated from the negative effect of rising world commodity prices because rapid global economic growth translated into higher exports, remittances and tourism. This changed with the onset of the subprime mortgage crisis in the United States. Since then global economic growth has slowed down and commodity price increases accelerated, at least for a while. ${ }^{61}$ As a result commodity importers faced significant negative terms of trade shocks and pressure on their fiscal stance.

One thing that commodity exporters and commodity importers have in common is that both must grapple with inflationary pressures. As we can see in Figure15 food price inflation has been on the rise in developing countries. What is the most adequate response to cope with inflationary pressures stemming from higher world food and fuel prices? The answer depends on the extent to which the increase in world prices is a real or a "monetary" phenomenon. If the increase were a "pure" change in the real price of

\footnotetext{
59 The terms “commodity exporters (importers)” actually refer to net commodity exporters (importers): i.e., those countries for which the revenues generated by commodity exports exceed (are below) the amount paid for commodity imports.

${ }^{60}$ For example, if the boom resulted in a large appreciation of their currencies eroding the competitiveness of their manufacturing and agricultural sectors and if the government spent the windfall as if it was permanent, countries could face serious difficulties when commodity prices fall. For decades this was the pattern for many countries in Latin America and Sub-Saharan Africa.

${ }^{61}$ As we saw in the previous section, these two events may be related because of the inflationary pressures unleashed by the lowering of US interest rates.
} 
food commodities, central banks have two options: to accommodate the price increases as a one-time spike in the rate of inflation or to suppress it through tight monetary policy. The former is preferable because it would avoid the negative impact that the latter has on economic activity. However, central banks that allow inflation to rise (in particular, if they allow it to exceed the set inflation targets) are putting their hard-won credibility at risk and this risk has to be weighed against the costs of tight monetary policy in terms of foregone output. Also, in countries in which wage and price indexation is widespread, it will be hard to prevent the initial increase in inflation from becoming entrenched.

Wage and price indexation, however, is much less frequent today than it was in the past. Given that fulfilling the inflation targets may mean that nonfood (with the exception of other commodities) prices must fall in nominal terms, some degree of accommodation might be desirable. ${ }^{62}$ Without it significant losses in economic activity are likely and this, in turn, would exacerbate the impact on poverty that food price increases produce directly. In addition, the recessionary impact of tight monetary policy would reduce the fiscal resources available to compensate the poor through targeted safety nets.

Thus, a prudent accommodation of the price increase whenever feasible is the best course of action. One way to make the transitory nature of the accommodation credible might be for the central banks and ministries of finance to openly acknowledge that this will be the course of action and negotiate some form of "pact" with the business sector, labor unions and other groups' representatives to avoid inflationary dynamics from unraveling. ${ }^{63}$ But if the signals are that inflationary dynamics are taking hold (for example, if nominal wages are increased by similar amounts as the general price increases), central banks will have to tighten monetary policy to stop them. An agreement with the IMF in which its task is to monitor whether monetary authorities and ministries of finance are treating the accommodation of the rise in inflation as temporary could be a way to strengthen the credibility of central banks and preclude inflationary expectations from becoming entrenched.

\footnotetext{
${ }^{62}$ Even the IMF (2008) has recognized that inflation targets might have to be missed in order to avoid an excessive reduction in output or output growth. Also, see Dervis (2008).

63 There are examples of successful wage-price "pacts.” For example, Israel and Mexico implemented successful incomes policies in the 1980s.
} 
For net importers, moreover, access to external resources from the IMF or other sources can allow them to adjust more gradually to the negative impact caused by higher food (and other) commodities prices on their balance of payments. External financing will help countries to adjust gradually to the new adverse circumstances but cannot be available to avoid them altogether. If this external financing is complemented with resources and policies to increase the levels of productivity and competitiveness, the adaptation of these countries to a negative environment could be turned into an opportunity.

A prudent accommodation of the food commodities price increase is the most desirable course of action if the latter represents a "permanent" change in the relative value of food (and other) commodities. To the extent that food commodities price increases are a monetary phenomenon, however, the appropriate policy response might be different. Insulating domestic prices from external inflationary pressures is correct. Even more so if the monetary commodity price cycle is likely to be subject to overshooting as happened in the period from mid-2007 to June 2008. One way to do this is to allow the nominal exchange rate to appreciate. This would imply that food commodities prices (and, therefore, food prices) in the domestic currency would rise more slowly. As a result, real incomes would not suffer or not suffer as much as the increase in the international food commodities prices would imply.

In the countries that are net exporters of commodities, a nominal (and real) appreciation of the domestic currency would be a natural by-product of the rise in revenues in foreign exchange resulting from the commodity boom. However, in the countries that are net importers of commodities this may not be an option given the impact that higher commodity prices have on their current accounts. If the governments in these countries want to see an appreciation of their currency, they will need to raise interest rates and as a result face a slowdown in their economic activity. This effect can be mitigated if countries have access to external funds. One natural candidate to provide these funds is the IMF.

However, relying mainly on a macroeconomic price such as the exchange rate may not be the best course of action. An exchange rate appreciation has its costs 
because it affects all tradable goods. By lowering the domestic price of tradables, it creates disincentives to exporters and hurts import-competing sectors in the economy. An appreciation which is not driven by higher domestic productivity, moreover, can slowdown growth. And if economic growth falls, so do fiscal revenues thereby exacerbating macroeconomic imbalances. Thus, if the increase in world commodity prices is partially a monetary phenomenon, implementing policies that are targeted to contain domestic price increases in specific markets may be appropriate.

A sensible alternative would be to use a combination of an appreciation of the exchange rate with policies targeted to specific markets to contain the domestic price increases of, in particular, food commodities. Among the targeted policies there are those which make use of controls such as price controls and export bans and those which use fiscal policy to affect prices such as changes in general price subsidies, export taxes, indirect taxes and import tariffs. In general, on efficiency grounds, the latter are preferable to the direct controls. The choice of which specific targeted policies to use should be based on "common sense" criteria. For example, governments should choose those price policy interventions which are more easily reversed (that is, they do not become hijacked by special interest groups), least distortionary, least regressive, more consistent with a rules-based trading system, simple to implement from an administrative point of view and do not cause unsustainable fiscal imbalance. ${ }^{64}$

How have countries been responding? The food price inflation data indicate that there has been some degree of accommodation. (Figure 15) There is also evidence that currencies from many developing countries have appreciated vis-à-vis the dollar. But a large number of governments have been implementing targeted measures to contain prices for specific food commodities. More than 80 developing countries for which data is available have put in place at least one of the following: reduced import tariffs, reduced indirect taxes, relaxed import restrictions, price controls, general consumer subsidies, export bans, export restrictions and export taxes. (Figure 16)

\footnotetext{
${ }^{64}$ Unfortunately, the information was codified in a way that does not distinguish between the use of controls vs. fiscal policy. In addition, there is no mention whether these measures were introduced as explicitly temporary or not.
} 
With the exception of import-liberalizing policies, the rest has elicited quite a bit of criticism from multilateral institutions. But targeted policies may be an appropriate response if price increases in world market are part of an inflationary process which originated in lower interest rates in the United States. As we saw in the previous section, there are reasons to believe that the recent acceleration in food commodities prices may be part of a global inflationary process. If this is true, part of the increase in food commodities prices is not a change in their "real” relative price (or opportunity cost) and governments from developing countries may be right in applying targeted measures to insulate domestic food prices from their behavior in international markets.

It is important to remember, however, that part of the increase in world food commodities prices is real and, thus, should be passed through to domestic prices. Policy interventions that attempt to retard the transmission of the change in international commodity prices to the domestic markets in full will be self-defeating because domestic producers and consumers will not adjust to the new price signals. Also, these measures can be very onerous from the fiscal point of view and inequitable in terms of the use of scarce government resources because, for instance, the benefits of many general subsidies largely accrue to the nonpoor. Hence, measures targeted to contain prices for specific food items should be applied in moderation and phased out when no longer necessary. The problem is that once implemented, new vested interests are born and the temporary nature of the interventions can go down the drain. The use of "pacts" or agreements with the business sector, labor unions and other representative groups as the ones mentioned above might we a way to avoid this.

The use of policy interventions that put a wedge between domestic and international prices exacerbates the price pressures in world markets for the affected commodities. Many of these unilateral decisions restrict the flow of food commodities in the international markets and, therefore, weakened a rules-based trading system. Without a credible multilateral solution to large food price fluctuations, however, it is not surprising that countries pursue what is perceived as best for them even if the rest of the world is worse off as a result. A rules-based trading system should include safeguards and mechanisms which would make the protection of domestic consumers and producers from large-and recurrent-- food commodities price fluctuations (in 
either direction) orderly and legitimate. One such mechanism is the creation of an international stock.

\section{Rising Food Prices and Poverty}

Until recently, analysts and policymakers used to be concerned that world food commodity prices were kept artificially low by agricultural support policies in advanced countries, thereby hurting millions of poor farmers in the developing world. ${ }^{65}$ Now, the concern is the opposite. With food prices sharply up, multilateral organizations and governments fear that the livelihoods of millions of poor consumers throughout the world have been put at risk. ${ }^{66}$

How can higher food prices be good and harmful to the poor at the same time? The answer is simple: the poor include both net buyers and net sellers of food in significant proportions. Small poor farmers benefit from higher food prices. However, the poor in urban areas and those in rural areas with little or no access to land are hurt, and hurt badly, when food prices increase. This contradictory impact of food prices on the poor has been called the "food price dilemma." 67 This dilemma has been the source of a futile debate regarding when the poor are better off: when food prices go up or when they go down? Rather than trying to measure and base the policy response on the net impact of higher (lower) food prices on poverty, policymakers should simply accept the unavoidable fact that if food prices rise (fall) poor net buyers (net sellers) will need help and rejoice in the fact that poor net sellers (net buyers) will be better off. In either case, safety net programs will have to be expanded in coverage and size to compensate the group of the poor who get hurt. In addition, when food commodities prices increase,

\footnotetext{
65 See, for example, Cline (2003), Hoekman and Olarreaga (2007).

${ }^{66}$ Although domestic food prices have not risen as rapidly as international prices, IMF (2008) estimates find that "the median 12-month rate of food price inflation for a sample of 120 non-OECD countries rose from 10 percent at end-2007 to 12 percent at end-March 2008, almost twice the median food price inflation rate of 2006.” (p.18). Similarly, World Bank (2008b) reports food inflation 2007/2008 for a group of countries and finds that food inflation rose by around $20 \%$ in Bolivia, Azerbaijan, Bulgaria and Costa Rica and reached a staggering 30\% in countries like Kyrgyz Republic and Sri Lanka.

${ }^{67}$ Timmer, Falcon and Pearson (1983), Chapter 1. This dilemma has been analyzed empirically for a number of countries. See, for example, Ackah and Appleton (2007); Barrett and Dorosh (1996); Deaton (1989); Lustig (1986); Mellor (1978); Pinstrup-Andersen (1987); Ravallion and van de Walle (1991); Ravallion (1990); Trairatvorakul (1984).
} 
there is an opportunity to help poor net sellers translate this windfall into a more longterm improvement in living standards.

As a general proposition, the impact on poverty generated by an increase in the price of food will depend on: i. the relative importance of different food commodities in the production set and consumption basket of different households and the difference between the two ${ }^{68}$; ii. the magnitude of the relative price change; and, iii. the degree to which households are compensated for the price shocks by changes in their income (i.e., by the indirect effect on wages and employment originated by the price change). ${ }^{69}$ Evidence suggests that: the poor spend between 60 and 80 percent of their income on food on average; the increase in domestic food price has been significant, and the positive effects on wages take time.

This is not the place to provide a comprehensive survey of the vast literature (dating at least as far back as the 1970s) of the impact of changes of food prices on poverty. The relationship has been analyzed using different methods ranging from partial to general equilibrium frameworks and an assortment of econometric techniques. For example, Deaton (1989) using a non-parametric method showed that an increase in the price of rice in Thailand benefits all households in the rural areas including the poor but urban households, including the poor, are made worse off. ${ }^{70}$ There are no direct estimates of the overall impact on poverty in this article, though. Ravallion and Van der Walle (1991) show that the impact of an increase in the price of rice in Indonesia on poverty is quite sensitive to the selection of the poverty measurement and the poverty line. ${ }^{71}$ They find that a price increase reduces the headcount ratio at a particular poverty line but raises it at lower poverty lines reflecting the fact that the poorest of the poor are net consumers of rice and that net producers are closer to the initial poverty line. When

\footnotetext{
${ }^{68}$ For poor farmers, the difference is often positive indicating that they benefit from a price increase. In contrast, poor urban households or landless agricultural workers are net consumers of food commodities and get hurt by an increase in their price.

${ }^{69}$ To estimate the latter, one must be able to estimate the spillover effects; this has been done using multisectoral and full-fledged computable general equilibrium models. Some CGEs are Walrasian, that is, all markets clear via prices and there is no unemployment. Others are more heterodox: they assume flexible prices in some markets but in others prices are determined as a mark-up above costs and total employment is endogenously determined by the level of aggregate demand.

${ }^{70}$ Deaton does not seem to see a problem with this outcome because there are fewer urban households, the urban poor spend a small fraction of their budget on rice and the urban households' income is much higher than rural household income

${ }^{71}$ They also show that and that the impact is not symmetric: that is, the elasticity of poverty with respect to a decrease in the price is different from the elasticity with respect to an increase in the price.
} 
they use distributionally sensitive measures (such as the FGT index), an increase in the price of rice has unambiguous negative effects on poverty (i.e., the index goes up) for all poverty lines and all distributionally sensitive measures. Using the Intensity of Consumption and Intensity of Production Coefficients, Lustig (1986) finds that an increase in the price of corn in Mexico has a negative impact on the incomes of the poor if both rural and urban poor are combined but if one disaggregates poor net buyers from poor net sellers, the former experience a negative but small effect while the latter experience a large positive effect which translates in an improvement in their diets. As in the case of Deaton, no overall measure of poverty is provided.

Overall, existing empirical evidence shows that an increase in food prices will make many of the already poor worse off and make some of the near poor (households with incomes just above the poverty line) poor. This, however, does not always translate into an increase in aggregate poverty (in, for example, the headcount ratio) because higher food prices also make part of the poor better off. But, there is a consensus that - at least in the short-run-- high food prices are bad for the poor because most of the poorest of the poor are net food buyers, even in rural areas and even where agriculture is the dominant activity ${ }^{72}$ That is, in the majority of countries, the net effect will be a higher poverty rate. However, as argued above, the net effect may not be the relevant indicator when deciding on the policy response. Even in countries where the net effect is a reduction in poverty, poor net buyers should have access to a broadened safety net system.

Furthermore, even if in the short-run higher food prices hurt more poor households than benefit them, could it be that in the medium-term higher incomes to net sellers induce higher incomes for net buyers through multiplier effects between agricultural and non farm incomes in rural areas? There is a large body of evidence that correlates higher agricultural incomes with higher non farm activity and incomes ${ }^{73}$; in general, studies show that the virtuous circle might take considerable time to manifest

\footnotetext{
${ }^{72}$ Ravallion (1989); Seshan and Umali-Deininger (2007); Byerlee, Myers and Jayne (2006); Christiaensen and Demery (2007); Jayne, Yamano, Nyoto, and Awuor (2001); Coady et al. (2008); Warr 2005. Simulations of the impact of the reduction of agricultural support policies in rich countries also show that in many countries first round effects of a price increase could hurt the poorest (Hoekman and Olarreaga, 2007).

73 For a survey see Haggblade, Hazel and Dorosh, 2007.
} 
itself. $^{74}$ In the short-run, the negative impact on the majority of poor households’ welfare is inevitable. In the case of the poor, the short-run effect is particularly important because the damage to health, nutrition and cognitive development might be irreversible.

What has been the impact of the recent increases in food prices on poverty? Table 6 presents a summary of recent studies. As one can observe, they use different methods, poverty lines and assumptions about price increases, pass-through to domestic prices, substitution effects, and wage (and other indirect income) effects. Also, some include net sellers while others don't. However, in spite of all these differences, on average, the evidence finds that in the majority of countries, higher food commodities prices increase poverty for practically all the food commodities.

The orders of magnitude of the estimated short-term impact of higher food prices on poverty are significant. Ivanic and Martin (2008) show that about 105 million people in the least developed countries have been added to the world's poor since 2005 because of rising food prices. This is equivalent to about 10 percent of the people living with less than a dollar a day and, according to the authors, and "close to seven lost years of progress in poverty reduction” (p.17). Even middle-income Latin America has not remained impervious: Robles et al.( 2008) estimate that the increase in world food prices between January 2006 and March 2008 resulted in an increase of 4.3 percentage points in the headcount ratio or 21 million additional poor individuals. ${ }^{75} \mathrm{CEPAL}$ (2008) - the UN Economic Commission for Latin America and the Caribbean-estimates that the ranks of the extremely poor and the moderately poor increased by 10 million each. The Asian Development Bank (2008) suggests that a 20\% increase in food prices would raise the number of poor individuals by 5.65 and 14.67 million in Philippines and Pakistan, respectively. ${ }^{76}$

It is important to point out that these estimates on the poverty impact of higher food prices do not take into account the positive effect that higher food commodities

\footnotetext{
${ }^{74}$ In the case of Bangladesh, for example, Ravallion (1989) suggests that secondary effects of rice price increases through labor markets could lead to higher incomes for the poorest after three to four years.

${ }^{75}$ Regional numbers for Latin America are own calculations based on Robles et al. (2008) country-bycountry estimations for net increase in poverty. ${ }^{75}$

${ }^{76}$ For a more extreme scenario of $30 \%$ increase in food prices, the number of poor people increases by 8.85 and 21.96 million in Philippines and Pakistan, respectively.
} 
prices has had on economic growth in net exporting countries. In these countries, the net effect of the commodity boom may well be a reduction in poverty. At present none of the estimates account for this impact. ${ }^{77}$ Since net exporters are fewer and richer than the net importers, the overall impact on poverty in low-income countries may not change much even if the commodity boom-driven growth dividend for net exporters is taken into account.

Throughout the developing world, poor net buyers will be adversely affected by higher food prices and net buyers living just above the poverty line are likely to become poor. Are developing countries ready to compensate these groups for their loss in purchasing power? In particular, do safety net programs exist and can they be easily expanded to incorporate the "new" poor? Do governments have the fiscal space to accommodate the additional resources needed to fund the safety net? Unfortunately, 19 (out of 49) low-income and 49 (out of 95) middle-income countries do not have safety net programs. Figure 21 presents the safety net programs available in low and middleincome countries by category: cash transfers, food for work, food ration/stamp and school feeding programs. Given the characteristic of the adverse shock-i.e., an increase in the price of a good that takes up a substantial portion of the poor person's budget - the most adequate safety net is to compensate the affected population for their loss in purchasing power in cash. Although cash transfers programs (conditional and unconditional) are increasingly more common, they are still not pervasive. According to Figure 21 there are 16 (out of 49) low-income and 37 (out of 95) middle-income countries that have cash transfers programs. School feeding programs are a bit more common in low-income countries that cash transfers programs but still only 24 of lowincome countries have such programs. While they will not compensate the poor for the loss of purchasing power associated with higher food prices, school feeding programs can insulate (at least in part) the children of poor households from suffering a cut in their food intake as a result of higher food prices.

In addition to the fact that there are many low- and middle-income countries which do not have safety net programs to help the poor who get hurt by higher food prices, those which do may have very limited coverage. In the case of Latin America

\footnotetext{
${ }^{77}$ CEPAL (2008) assumes that incomes rose at the same pace as the consumer price index.
} 
and the Caribbean, for example, the coverage of cash transfer programs exceeds 25 percent of the population living in poverty in 8 out of 26 countries: Brazil, Colombia, Chile, Ecuador, Honduras, Jamaica, Mexico and Panama. The poorest countries in the region either do not have programs or have them in a very limited scale.

Furthermore, most of these programs do not have a mechanism to incorporate the "new" poor or increase the size of the benefit in the face of adverse shocks as part of their design. Some governments (Brazil and Mexico, for example) have increased the amount of the transfer to compensate for the loss in its purchasing power. However, the programs have not incorporated as beneficiaries those who became poor as a result of the food price increase. So far it is not clear how many of the countries which have cash transfers programs increased the amount of the transfer and incorporated the "new" poor into the program (or implemented a complementary program).

In sum, the existing safety net system in developing countries leaves much to be desired. In too many countries it is either inexistent or small; and, even in the countries in which cash transfers programs are large and effective in addressing chronic poverty, they are not designed to respond to shocks. This means that the majority of the poor who have been hurt or those who have become poor as a result of higher food prices are not being protected from the impact of higher food prices on their living standards. In the cases in which these programs have been expanded, this was done as an ad hoc measure implemented many months (or even years) after food price increases appeared in the scene.

Low-income countries for whom higher commodity prices represent a negative terms of trade shock may not have the fiscal space to finance an expansion let alone launch a new safety net programs. There is no available data in the public domain as to how many countries may be in such position. ${ }^{78}$ These countries are candidates for receiving multilateral support in the form of grants or concessional loans whose destination should be to fund the safety net programs to cope with rising food prices. The World Bank, for example, has already approved more than 120 million dollars of grants primarily (from its Food Price Crisis Response Trust Fund funded from Bank

\footnotetext{
${ }^{78}$ IMF (2008) indicates which countries need the IMF because of balance of payments vulnerability but there is no indication how many countries may need it to expand or implement a safety net.
} 
surplus) to bolster the safety net system in 14 low-income countries and an additional 400 million dollars is in the pipeline.

Should the overriding policy recommendation be to implement cash transfer programs as quickly and as in many countries as possible? The answer is yes. These programs are key to help "pure” and net buyers of food cope with rising food prices, but as long as they have an "insurance" component: that is, as long as cash transfer programs are able to incorporate the "new" poor and adjust their transfers fast enough. As mentioned these programs where they exist have not been designed with an "insurance" component in mind. It will be necessary to analyze whether cash transfer programs can be adapted to incorporate an "insurance" component and what does this imply in terms of their institutional design and implementation.

Are there other measures that can be implemented to help poor consumers cope with rising food prices? De Janvry and Sadoulet (2008) suggest that measures geared to increase access to land and improve the productivity of subsistence and belowsubsistence farmers can be a more appropriate intervention particularly in the case of poor countries. In low-income countries between 80 and 90 percent of the poor live in rural areas and between two thirds and three fourths of them have access to a plot of land. However, even if they home produce some of the food they consume, most of them are net buyers of food and are hurt by higher food prices. If this group could have more access to land and/or increase the productivity of the land they already have, one could achieve two goals simultaneously. First, one could reduce the impact of higher food prices on the rural poor by lowering the amount that must be purchased by them in the market and converting those with sufficient assets into self-sufficient farmers or even marginal net sellers. Second, one could begin to address the supply-side constraints on food commodity production mentioned in Section 1 at the lower end of the spectrum. De Janvry and Sadoulet recommend that policy measures should increase the access to: improved seeds and fertilizers for crops, and to small animals; credit to purchase inputs; more land; and, technical assistance.

We have seen that higher food prices makes large numbers of the already poor poorer and some of the nonpoor poor. But could this impact on poverty translate into lower long-run economic growth? In low-income countries with little or no agricultural 
potential if food becomes "permanently" more expensive, we could start to witness the process described by Nobel Prize Laureate Robert Fogel in reverse. ${ }^{79}$ Fogel demonstrated that-by increasing the amount of energy available for work and the human efficiency in transforming the dietary energy due, for example, to a lower incidence of disease-- improvements in the UK's diet could account for as much as 30 percent of the growth between 1790 and $1980 .{ }^{80}$ By the same token, if higher food prices lead increasing numbers of people in poor countries to downgrade their diet (in quantity and quality) for a sustainable period, long-run economic growth in those countries would fall. This, in turn, would cause progress on the poverty front to slow down in the long-run even further.

The opposite could happen in low-income countries with large numbers of marginal net sellers of food commodities for whom higher food prices would translate into better living standards. As these groups become better nourished and more productive, long-term economic growth could be higher than before. What policy interventions could help lock in the windfall of higher food prices into sustained higher standards of living? Clearly one course of action would be to combine the policies proposed by de Janvry and Sadoulet to improve the productive potential of marginal net sellers and subsistence farmers with programs designed to improve the human capital of children in these households through interventions that would focus on nutrition, education and health.

\section{Conclusions}

World food commodities prices have risen substantially in the past six years. The IMF's index of internationally traded food commodities prices increased 130 percent from January 2002 to July 2008. Individual agricultural commodities show even more pronounced increases. Although food prices have risen since 2002, the rate at which food prices increased accelerated in the past year. Between July 2007 and June 2008 prices rose by 42 percent; this is equivalent to a third of the increase observed from January 2002 onwards in 15 percent of the time. Since July 2008, food commodities prices began to fall. While this decline comes as a relief, prices are likely to stay high in the foreseeable future.

\footnotetext{
${ }^{79}$ Fogel (1994).

${ }^{80}$ Fogel (1991).
} 
The increase in food commodities prices has been driven by three main factors. First, food commodities prices rose because of supply-side constraints while demand for food consumption continued to grow at the expected rates. This caused a reversal in the long-term trend of declining food commodities prices whose first symptoms were felt at the beginning of this decade.

Second, support policies for the production of biofuels implied a shift in demand for a subset of food commodities especially after 2005. In addition, rising energy prices resulted in higher costs for the production of food and, perhaps more importantly, in the opportunity cost of growing crops for food consumption purposes as opposed to inputs for the production of biofuels. Idiosyncratic factors such as bad weather and disease exacerbated the pressures on specific years. The "discovery" of biofuels caused a structural shift in the demand and supply functions of grains and oilseeds (with both a horizontal and vertical shift in demand and a vertical shift in supply). Everything else equal, the real price of food commodities is likely to stay higher, significantly higher than anticipated before this new source of demand came into the scene. A corollary of the surge in biofuels, for the first time in history agricultural, energy, and environmental policies need to be integrated.

These factors are the "real" forces—-that is, factors that affect the true opportunity cost of food commodities-- that are behind the reversal of the downward secular trend in food commodities prices. However, this is not the end of the story. The acceleration in food commodities price increases since mid-2007, can be accounted for more by monetary factors (which affect the prices of all commodities, not just food) than forces affecting the "true" long-run opportunity cost of food commodities. Among the monetary factors two stand out: the depreciation of the dollar and the fall in US interest rates. The depreciation of the dollar has stimulated demand for commodities in the countries whose currencies appreciated vis-à-vis the dollar. In addition, suppliers have probably adjusted upwards their price in dollars to reduce their losses.

However, prices of commodities rose in all "strong” currencies (albeit at a slower pace than in dollars), so other factors were at play. One obvious candidate is the global inflationary pressures triggered by monetary policy in the United States 
following the onset of the subprime mortgage crisis. Commodity prices tend to adjust faster than prices of manufacturing goods so when these prices catch-up or inflationary expectations are adjusted downward, the real commodity prices will return to their longrun "true" equilibrium. Lower interest rates in the US led to portfolio shifts away from interest-bearing instruments into other assets including commodities. This shift probably caused short-run prices of commodities to rise even further. Arbitrage conditions in the allocation of investment funds among alternative assets could explain how lower interest rates caused the transitory overshooting of nominal (and, of course, real commodity) prices experienced between October 2007 and July 2008.

In sum, the recent acceleration in food commodities prices may be mostly a "monetary" phenomenon: that is, part of a global inflationary process and a reflection of the different velocities of adjustment in prices with commodities taking the lead. The acceleration in price increases was exacerbated by policy interventions (such as export restrictions and general consumption subsidies or price controls) which curtailed the supply of some key food commodities in world markets that were already stressed by both "fundamentals" and the portfolio shifts triggered in the aftermath of the subprime mortgage crisis in the United States.

One key policy dilemma is to what extent governments should allow the changes in international food commodities prices to be passed through to domestic prices. Since as argued here, part of the increase is real, domestic prices in developing countries should gradually adjust to send the right signals to domestic producers and consumers. In the transition, these price increases should be accommodated as a once-and-for-all spike in inflation because the alternative-which might require other prices to fall in nominal terms-would be too costly in terms of foregone economic activity.

Governments could resort to negotiating agreements or "pacts" with the business sector, labor unions and other groups' representatives to avoid inflationary dynamics from becoming entrenched. These agreements might be easier to obtain when the government commits to protecting low-income groups from the brunt of the price increases through cash transfers programs or targeted subsidies. In some cases, an agreement with the IMF in which the institution is tasked with monitoring whether monetary authorities and ministries of finance are treating the accommodation of the 
rise in inflation as temporary could be a way to strengthen the credibility of central banks and preclude inflationary expectations from becoming entrenched. But if the effort to contain inflationary dynamics fails, tight monetary and fiscal policies will be inevitable.

As suggested in this paper, however, not all the increase in international food commodities prices is a change in their relative price. There are reasons to believe that part of the increase reflects global inflationary pressures. In this case partially insulating domestic prices from their behavior in international markets is the appropriate policy response. One course of action is to allow the nominal exchange rate to appreciate. This would imply that food commodities prices (and, therefore, food prices) in the domestic currency would rise more slowly or in the extreme case not rise at all. As a result, real incomes would not suffer or not suffer as much as the increase in the international food commodities prices would imply.

However, an exchange rate appreciation has its costs. By lowering the domestic price of tradable goods, it creates disincentives to exporters and exposes domestic producers to unwarranted competition from cheaper imports. Another course of action would be to use a combination of an appreciation of the nominal exchange rate with policies targeted to contain price increases of specific food commodities. These policies are of two kinds: those which use controls (such as price controls and export bans or restrictions) and those which use fiscal policy (such as reducing indirect taxes and tariffs, raising export taxes, increasing general subsidies and so on). Policies that do not make use of controls are preferable on efficiency grounds. As a general proposition, governments should choose the price policy interventions which are more easily reversed (that is, they do not become hijacked by special interest groups), least distortionary, least regressive, more consistent with a rules-based trading system, simple to implement from an administrative point of view and do not cause unsustainable fiscal imbalance.

Evidence shows that in most developing countries there has been a combination of inflation accommodation, appreciation of the exchange rate and targeted price interventions. The latter have elicited quite a bit of criticism from the international organizations. However, as argued in this paper, if they are temporary and used with 
moderation, targeted price interventions may be an appropriate response to cope with external inflationary pressures and the large fluctuations that commodity prices experience in the process. While it is true that these policies can exacerbate price increases in the international markets, in the absence of a multilateral response it should come as no surprise that countries choose unilateral protection. A rules-based trading system should include safeguards and mechanisms which would make the protection of domestic consumers and producers from large-and recurrent-- food commodities price fluctuations (in either direction) orderly and legitimate. One such mechanism is the creation of an international stock.

The impact of rising food prices on poverty has been the subject of some debate. When food prices rise (fall) poor net consumers (poor net sellers) of food get hurt and poor net sellers (poor net consumers) are better off. Available evidence suggests that in the majority of countries, an increase in food prices is likely to result in an increase in overall poverty. In this paper I argue that to concentrate on the net effect may not be the right approach. Governments and multilateral organizations should accept that there will always be part of the poor who get hurt — and often severely — by higher, or lower, food commodities prices. The appropriate policy response is to have safety nets to help those who get hurt.

In the present case, the best policy measure would be to compensate the net buyers for their loss in purchasing power in cash. However, many developing countries do not have cash transfers programs in place or when they do, their coverage is limited. Many countries do not have the fiscal resources or administrative capacity to launch such programs or expand their coverage. In addition, the cash transfers programs were not designed to cope with shocks. Their coverage does not expand automatically to incorporate those who became poor as a result of food price increases. Nor is the size of the transfer increased automatically to compensate beneficiaries for the loss in purchasing power due to higher food prices. Further analysis will be required to determine whether these programs can be used as an effective safety net in the event of food price (and other systemic) shocks and what would this entail in their institutional design. Multilateral organizations can help countries design, implement and finance an adequate safety net system to mitigate the impact of higher food prices on poor net consumers. 
Since many of the extreme poor in low-income countries live in rural areas and between two thirds and three fourth of them have access to small plots of land, policy interventions that would further expand their access to land and increase the productivity of their plots could kill two birds with one stone. Greater access to improved seeds, fertilizers and small animals, credit to purchase inputs and land, and technical assistance could reduce the impact of higher food prices on the rural poor. These policies would lower the amount that must be purchased by them in the market and convert those with sufficient assets into self-sufficient farmers or even marginal net sellers. These measures would also help address the supply-side constraints on food commodity production for the extreme poor living in rural areas in low-income countries. Multilateral organizations can help countries design, implement and fund programs whose main objective is to enhance the productive capacity, and thereby improve the food security, of millions of poor farmers throughout the developing world. 


\section{FIGURES AND TABLES}

Figure 1. Evolution of Real Food Commodity Prices (2007=100), January 1957-June 2008

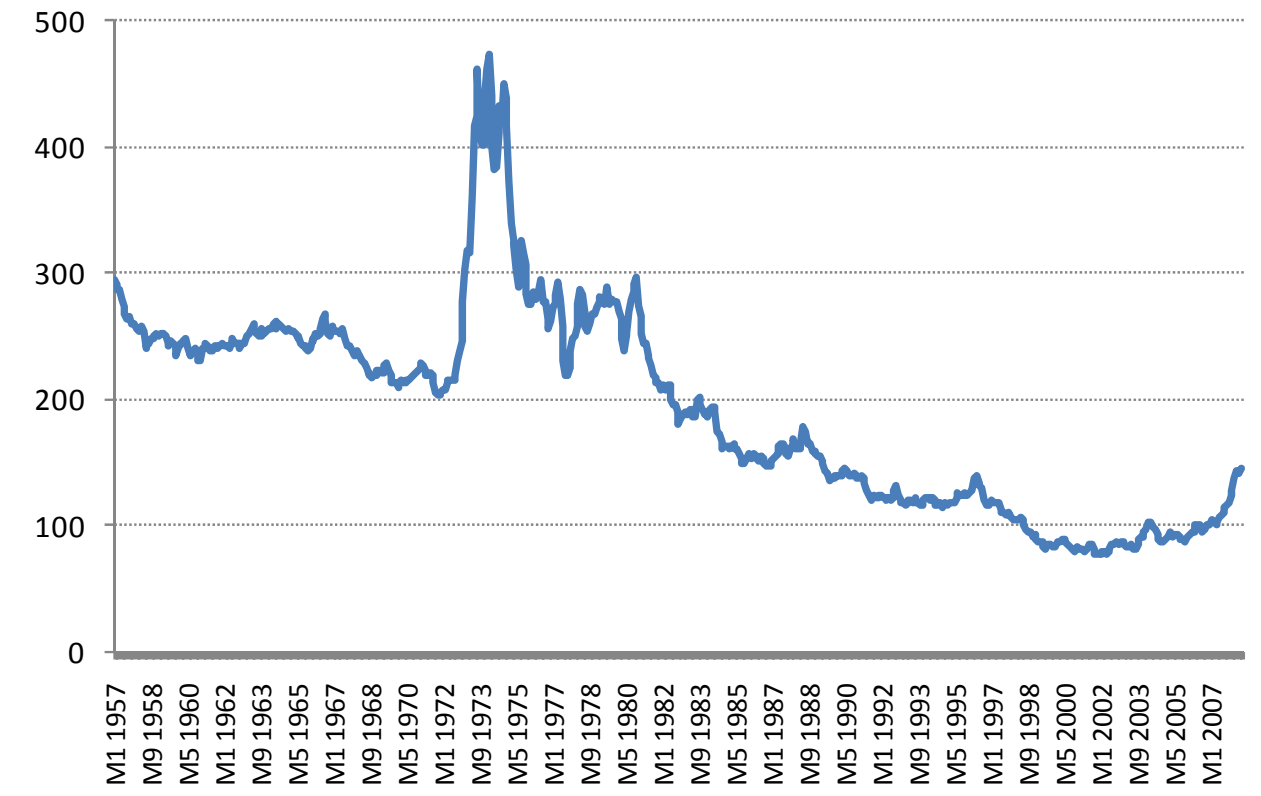

Source: International Financial Statistics, IMF.

Notes: It refers to a Food Commodity Price Index including bananas, cereals, meat, vegetable oils, seafood, oranges and sugar. Deflated by the US CPI.

\section{Figure 2. Food Commodity Price Index (2005=100), January 2002-August 2008}

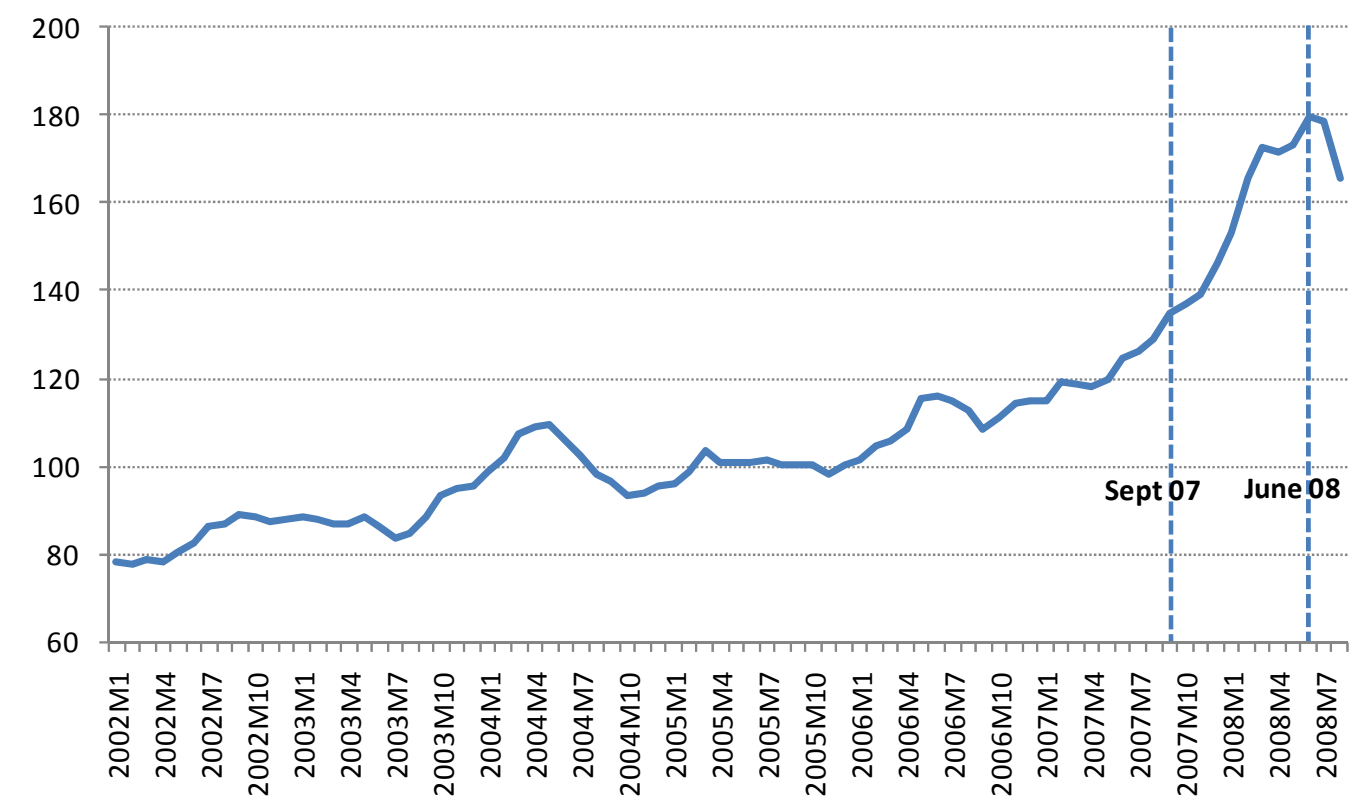

Source: IMF Primary Commodity Prices Database. 
Figure 3. Food Commodities Prices, January 2002-August 2008

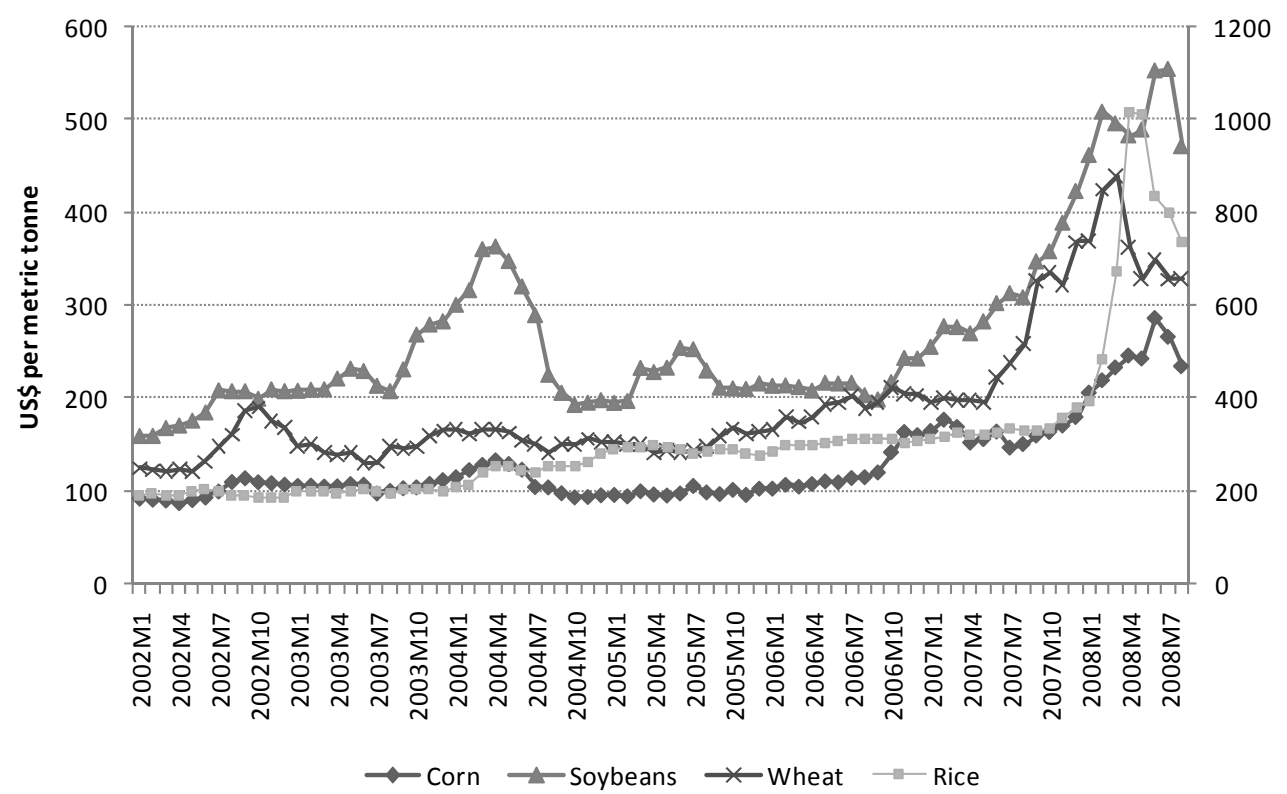

Source: IMF Primary Commodity Prices Database. Commodity prices refer to: Maize (corn), U.S. No.2 Yellow, FOB Gulf of Mexico, U.S. price, US\$ per metric tonne; Rice, 5 percent broken milled white rice, Thailand nominal price quote, US\$ per metric tonne; Soybeans, U.S. soybeans, Chicago Soybean futures contract (first contract forward) No. 2 yellow and par, US\$ per metric tonne; Wheat, No.1 Hard Red Winter, ordinary protein, FOB Gulf of Mexico, US\$ per metric tonne.

Figure 4. World Stocks-to-Use Ratio for Grains and Vegetable Oils (in percent), 1960/612008/09

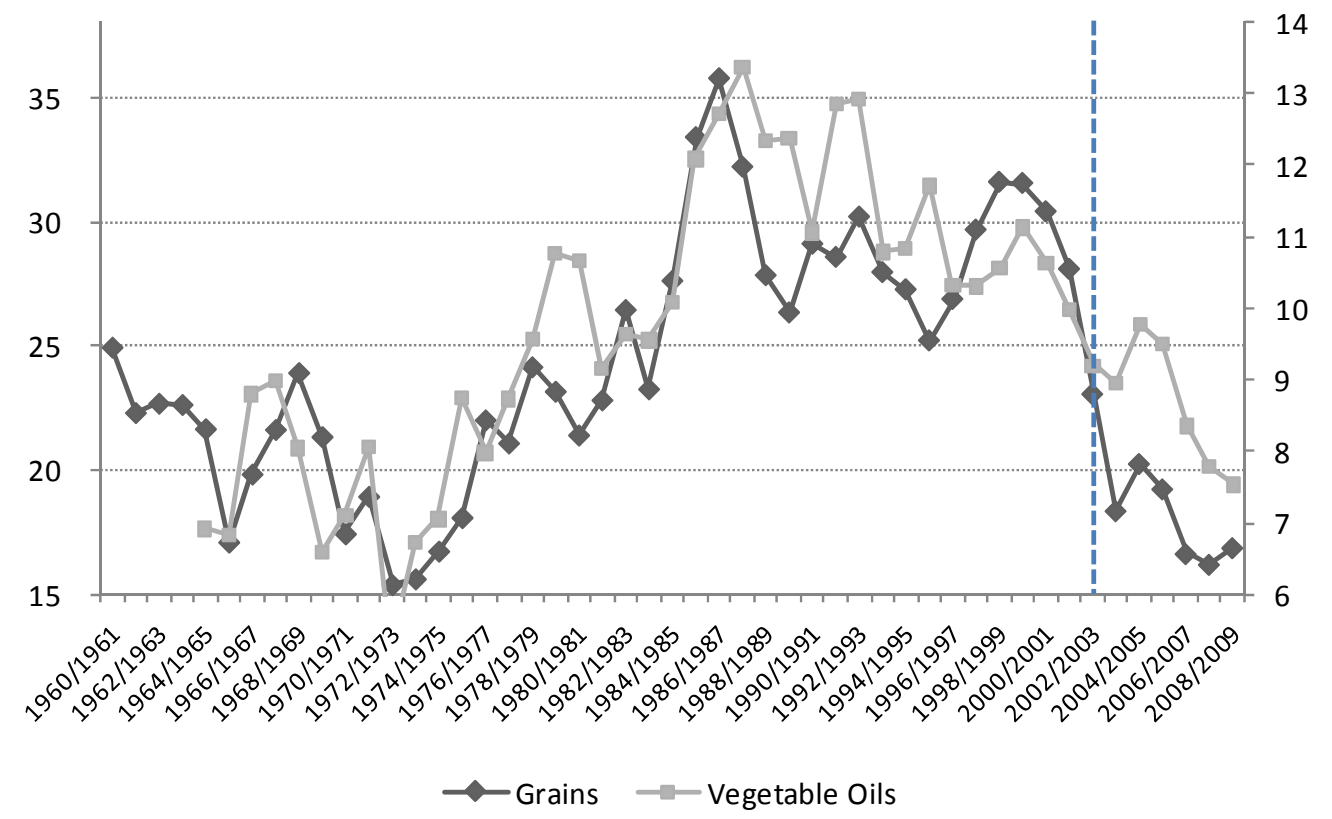

Source: Author's construction based on data from the PSD Database, USDA.Notes: Ratio is calculated using total domestic consumption and ending stocks. In top figure, right axis is for vegetable oils. For grains, it includes barley, corn, millet, mixed grain, oats, rice, rye, sorghum and wheat. For vegetable oils it includes coconut, cottonseed, olive, palm, palm kernel, peanut, rapeseed, soybean and sunflowerseed oils. The vertical line indicates the date after which the stocks-to-use ratio undergoes a relatively sharp drop: from a yearly average equal to 27 percent between 2000/01-2002/03 to 18 percent between 2003/04-2007/08. 
Figure 5. Demand of Corn for Fuel in the United States and Evolution of Corn prices

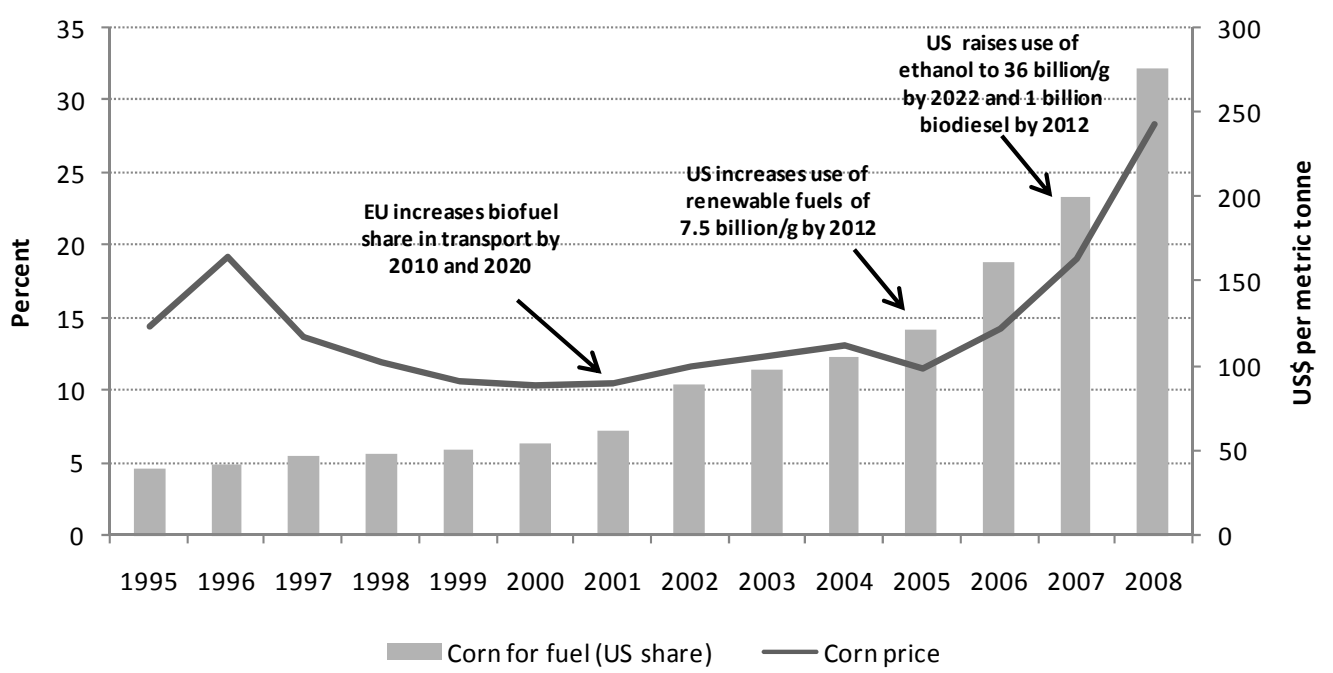

Source: Author's construction based on the IMF Primary Commodities Database and USDA Feedgrains Database. Information for mandates is from Table 3.

Notes: Prices refer to Maize (corn), U.S. No.2 Yellow, FOB Gulf of Mexico, U.S. price (average of daily quotations). Calculations of corn for fuel are for the United States. Corn prices for 2008 are averages from January 2008 to July 2008.

Figure 6. Corn and Soybeans prices and U.S. Ethanol Production, 1995-2007

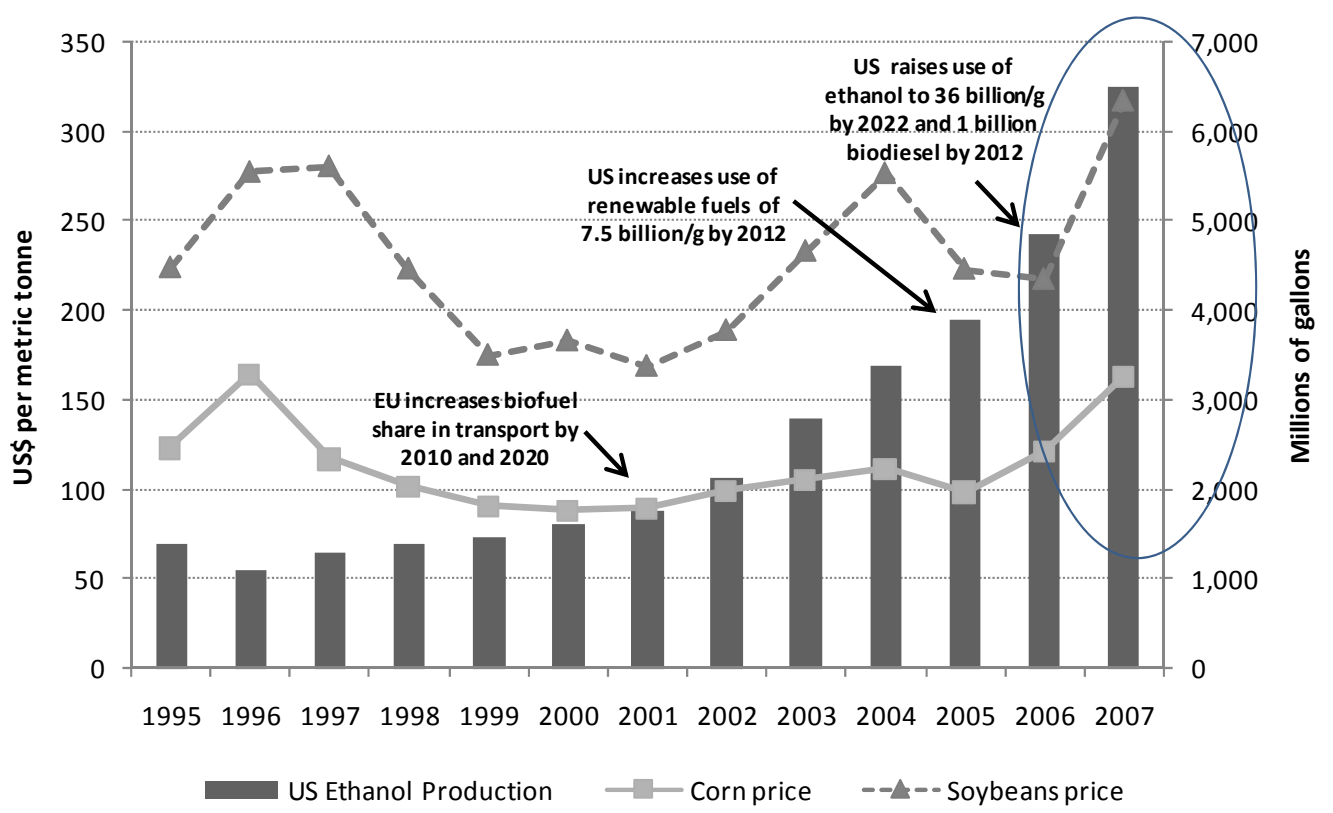

Source: Author's construction based on IMF Primary Commodity Database and Renewable Fuels Association. Information for mandates is from Table 3.

Notes: Ethanol production is for the United States. Prices refer to Maize (corn), U.S. No.2 Yellow, FOB Gulf of Mexico, U.S. price (average of daily quotations); Soybeans, U.S. soybeans, Chicago Soybean futures contract (first contract forward) No. 2 yellow and par (average of daily quotations). 
Figure 7. Gasoline prices and U.S. ethanol production, 1995-2007

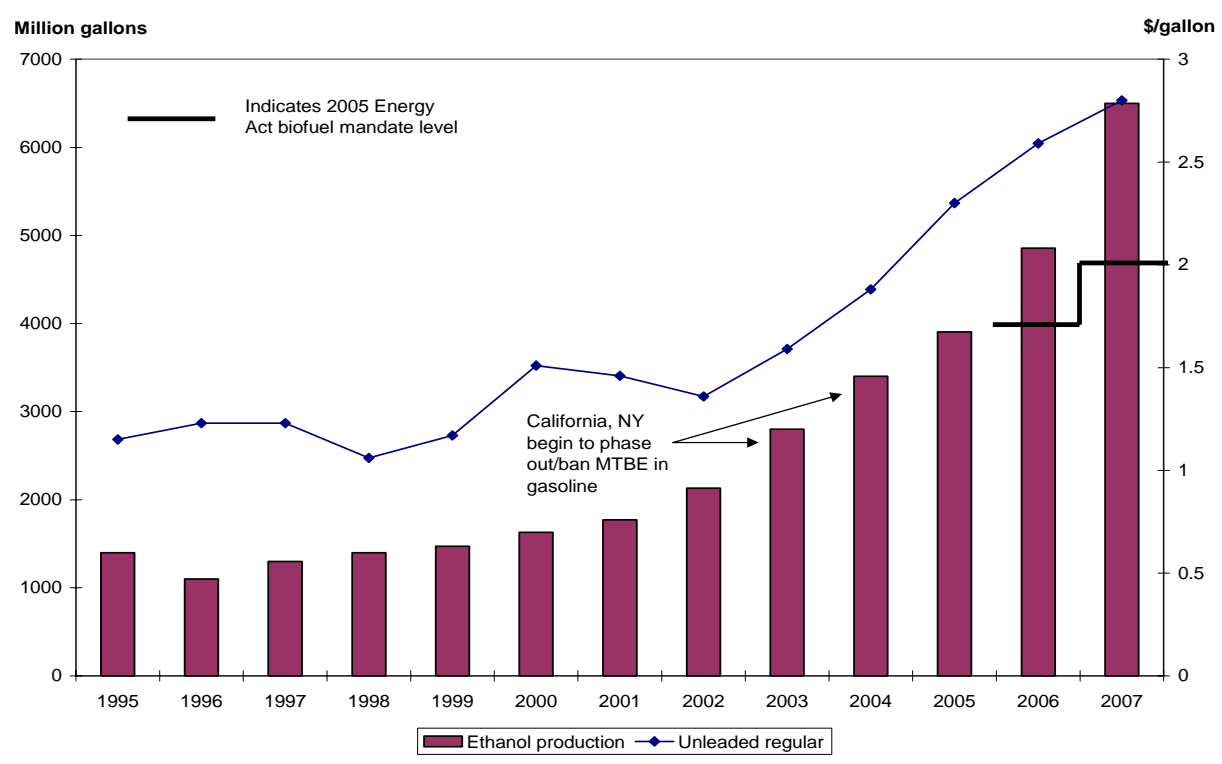

Source: Elliott (2008).

Figure 8. Export Restrictions and the Price of Rice, June 2007-July 2008

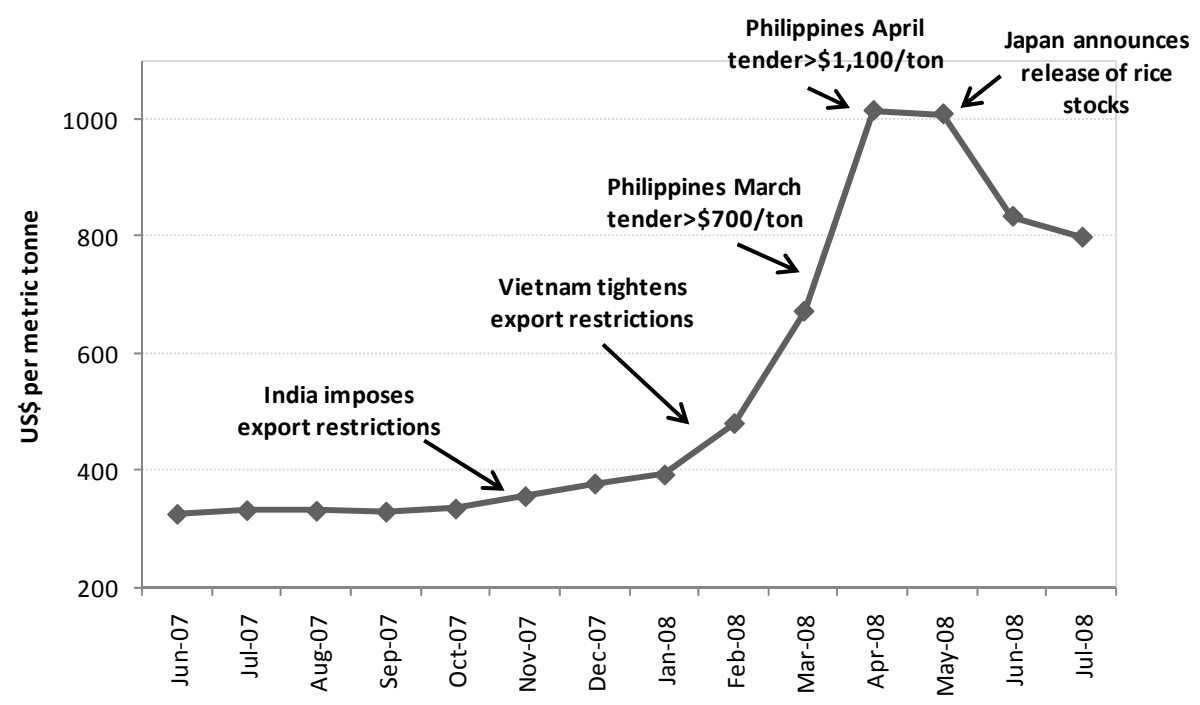

Source: IMF Primary Commodity Prices Database. Export policies from Slayton and Timmer (2008) and Timmer (2008). Based on a graph by Slayton and Timmer (2008). 
Figure 9. The Dollar and Food Commodities Prices, January 2000-June 2008

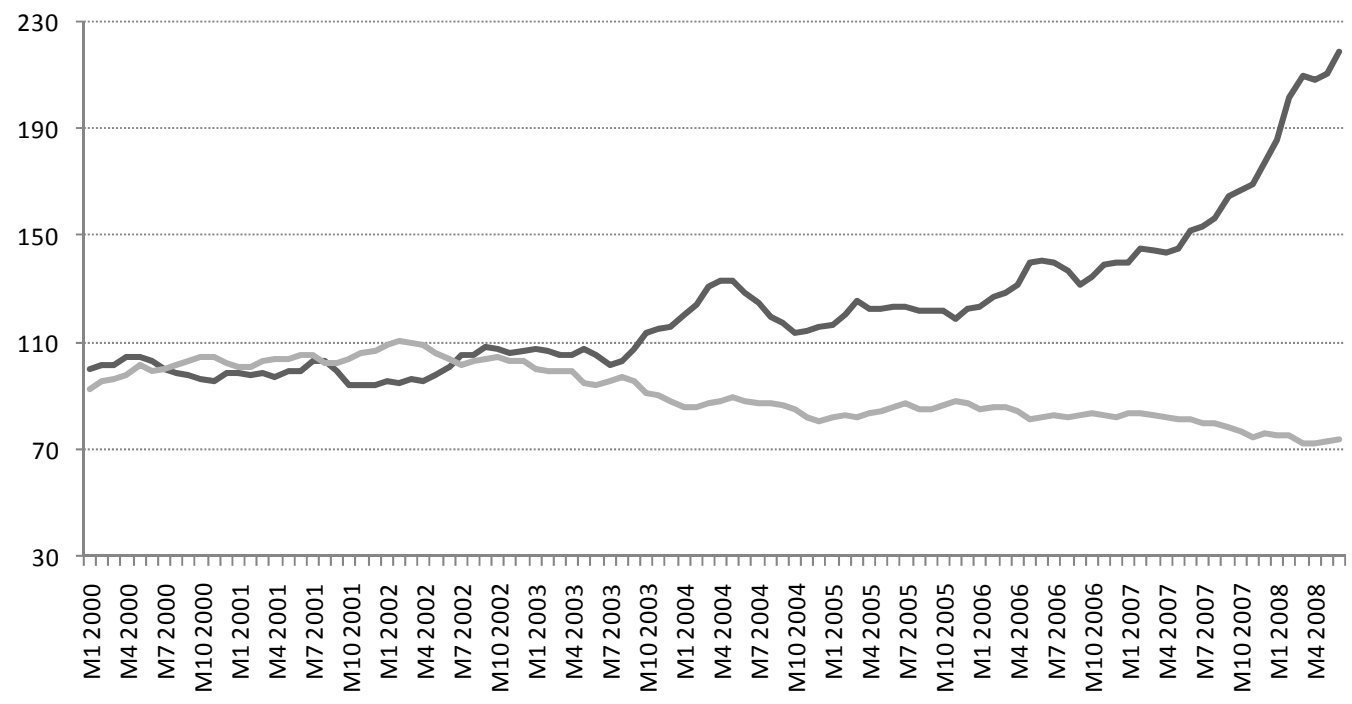

- Food prices $\quad$ REER

Source: Author's construction based on data from the International Financial Statistics, IMF.

Notes: The real effective exchange rate (RER) refers to the US real exchange rate $(2000=100)$ based on RNULC (Relative Normalised Unit Labour Cost). Food prices refer to a food commodities price index $(2000=100)$.

\section{Figure 10. Non-fuel Commodity Prices in Major Currencies, January 2000-June 2008}

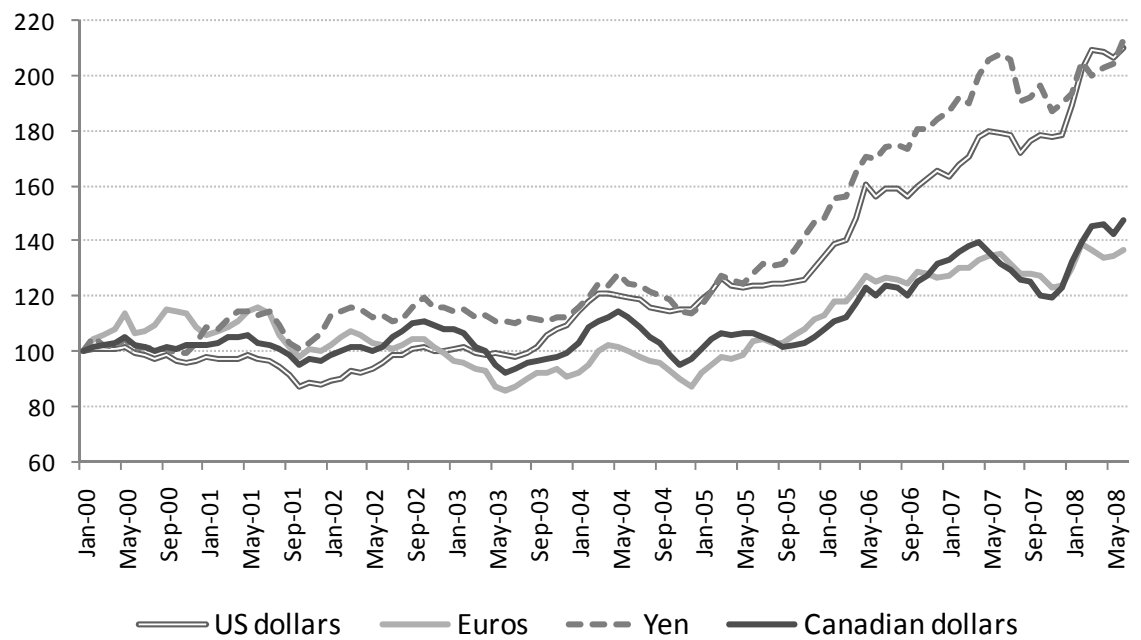

Source: Author's construction with data from IFS, IMF for prices and OECD Stat for exchange rates. 
Figure 11. Monetary Policy in the U.S. and Food Commodities Prices, June 2006June2008

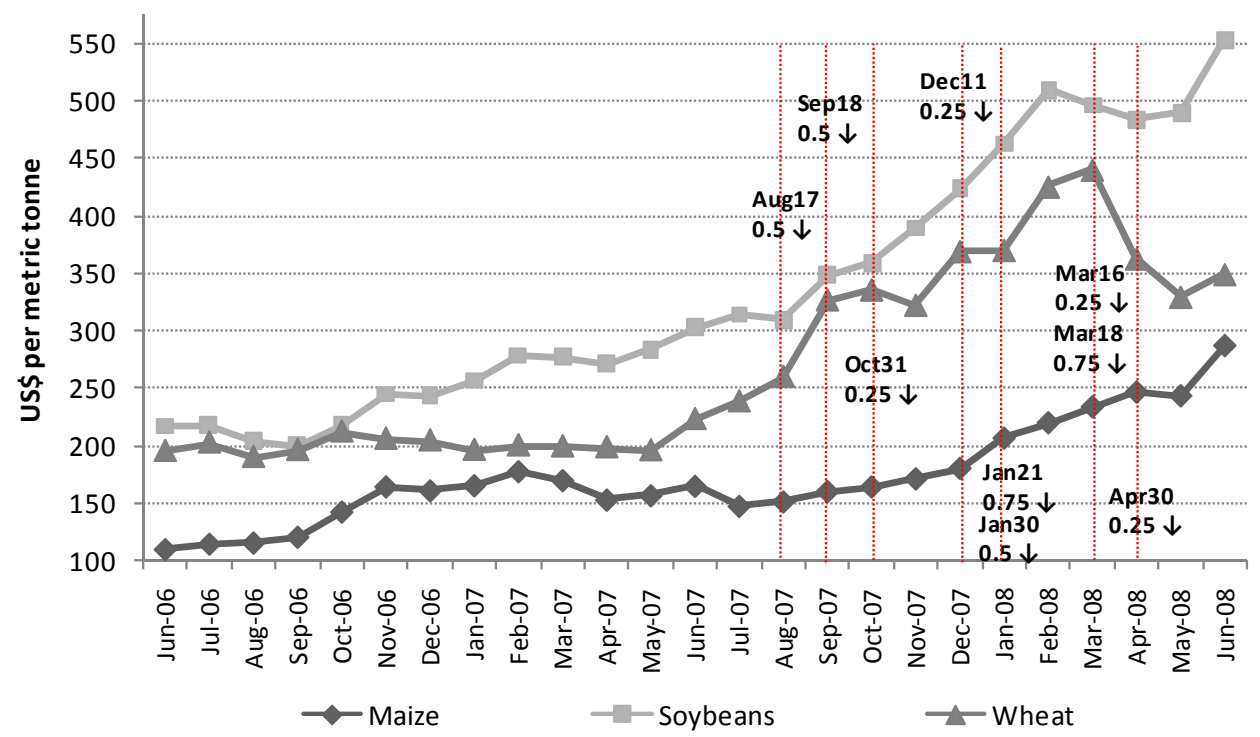

Source: Author's construction based on data from the IMF Primary Commodity Prices Database and Federal Reserve.

Notes: Vertical lines shows periods in which the Fed's primary credit rate was lowered as specified in the graph's text. The primary credit rate fell from 6.25 in June 2007 to 2.25 in June 2008 (the discount rate is the interest rate charged by the Fed to commercial banks and other depository institutions on short-term loans (overnight)). The federal funds rate started to fall in August 2007 (after stability since mid-2006) from 5.02 to 2.01 by July 2008 ("the federal funds rate is the interest rate at which depository institutions lend balances at the Federal Reserve to other depository institutions overnight"; for more information visit www.federalreserve.gov). IMF prices for each product refer to: (i) Maize (corn), U.S. No.2 Yellow, FOB Gulf of Mexico, U.S. price (average of daily quotations); (ii) Soybeans, U.S. soybeans, Chicago Soybean futures contract (first contract forward) No. 2 yellow and par (average of daily quotations); (iii) Wheat, No.1 Hard Red Winter, ordinary protein, FOB Gulf of Mexico (average of daily quotations). 
Figure 12. Real Interest Rate and Real Food Commodity Prices, January 2007 - July 2008

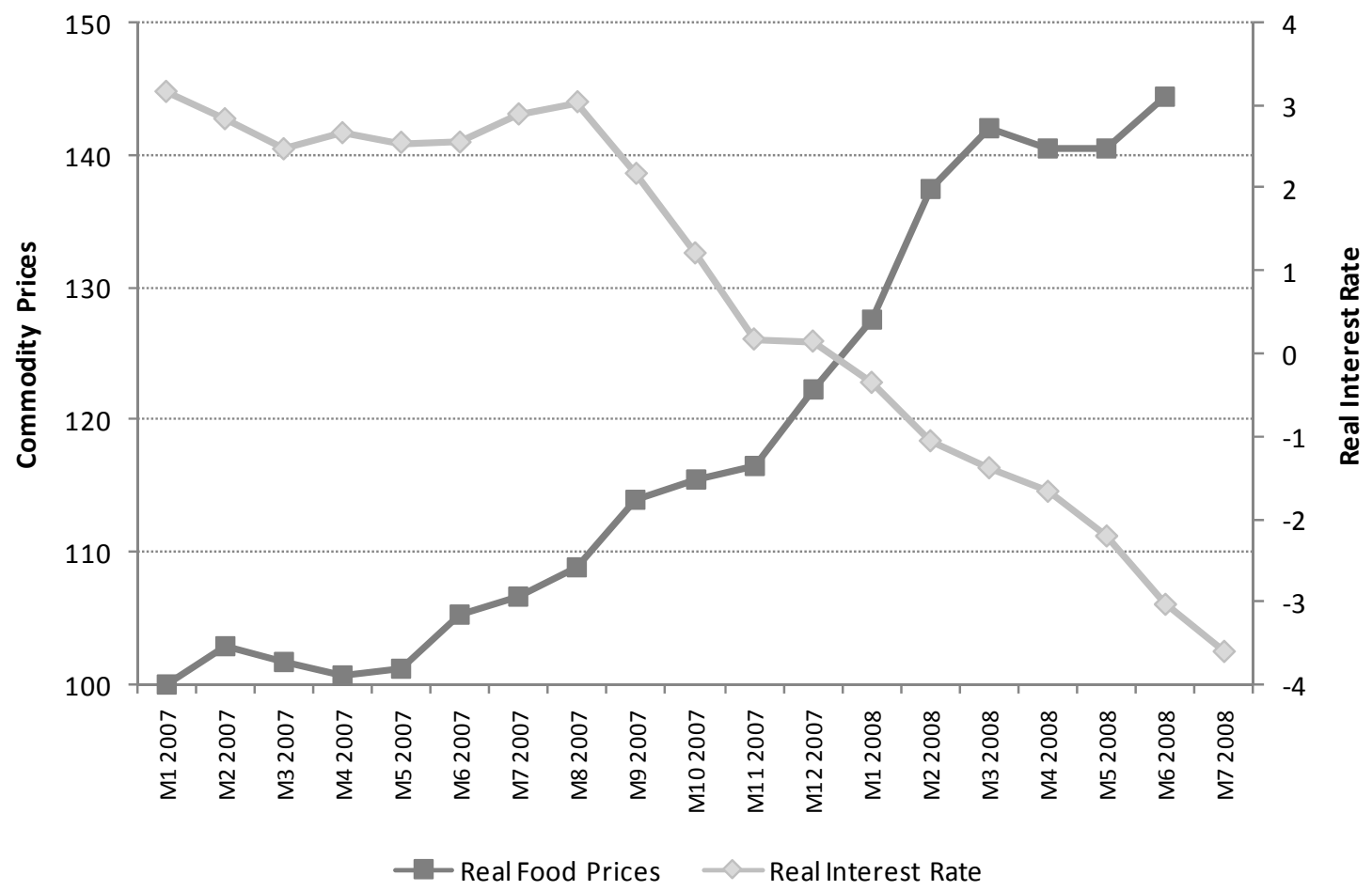

Source: Author's construction with data from the IMF Primary Commodity Database and IMF International Financial Statistics.

Notes: Real interest rate is the Federal Funds Rate adjusted for previous year (12-month) inflation. The food commodity price index (Jan $2007=100$ ) is adjusted for U.S. inflation. 
Figure 13. Food Protests, January 2007-May 2008

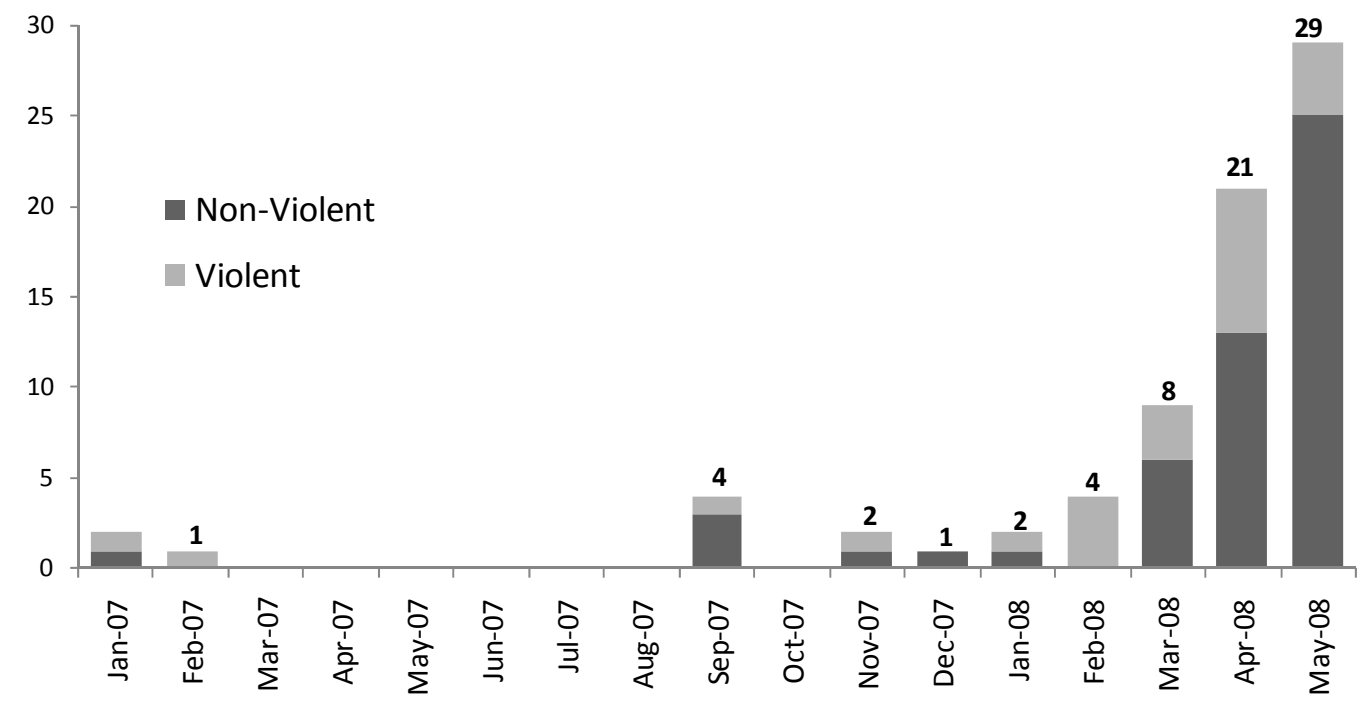

Source: From Von Braun (2008d).

Notes: Von Braun (2008) considers as non-violent food protests the strikes, protests, riots on food or agriculture related issues (since Jan. 2007) and as violent food protest those involving the use of physical force and/or resulting in casualties. 
Figure 14. Number of Countries with Positive and Negative Impact on Current Account from World Food and Oil Price Increases

\section{PRGF-Eligible Countries}

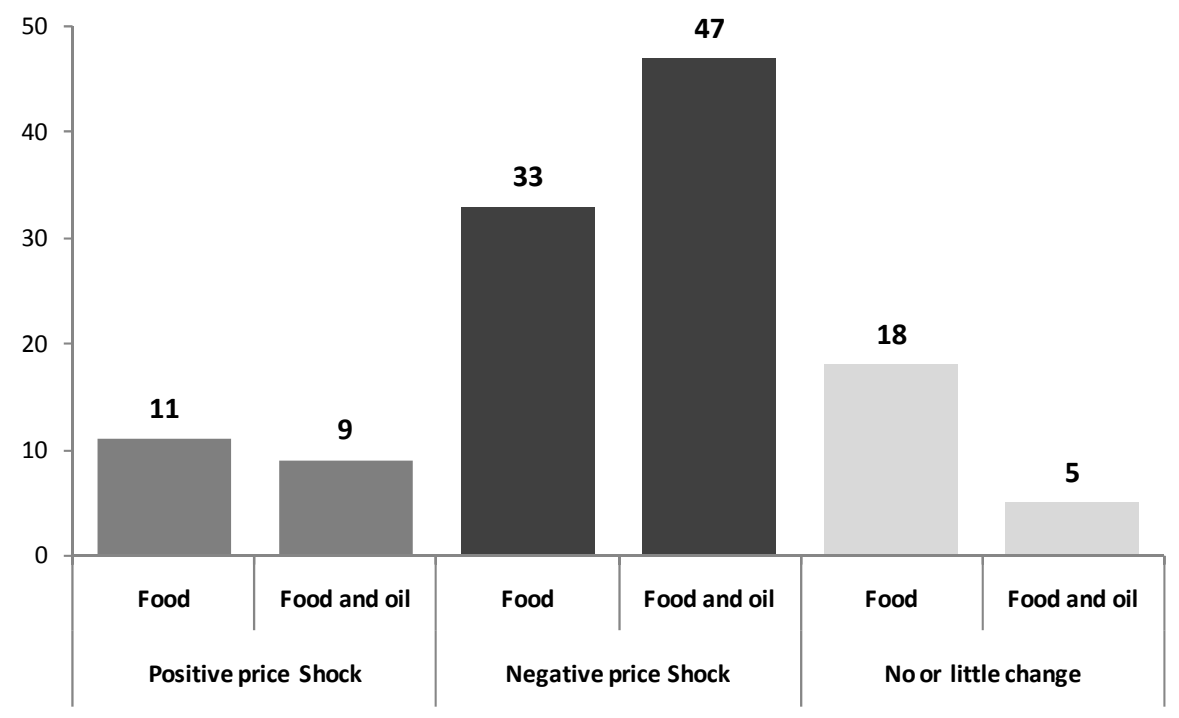

Middle-Income Countries

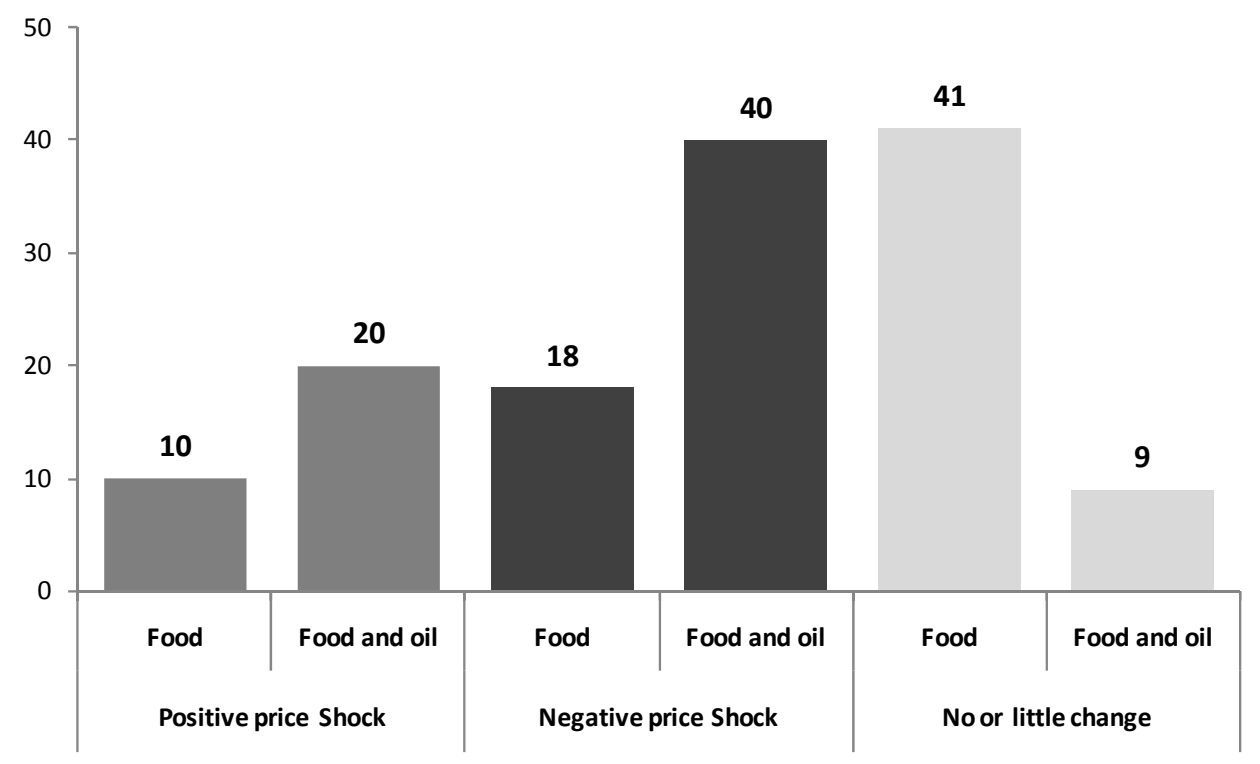

Source: Author's construction based on data from IMF (2008)- Tables 1a and 1b.

Notes: Positive and negative price shock refers to changes in the current account (as \% of GDP) equal to or larger than 0.5 in each direction. The total number of countries considered is 62 for food shocks and 61 for combined shocks for the IMF'S Poverty Reduction and Growth Facility (PRGF) eligible countries and 69 middle-income countries. Countries with missing information are not included. PRGF-eligible countries are those eligible for the IMF's Poverty Reduction and Growth Facility (a low-interest lending facility for low-income countries). 
Figure 15. Median Inflation in 120 non-OECD countries (y-o-y, in percent)

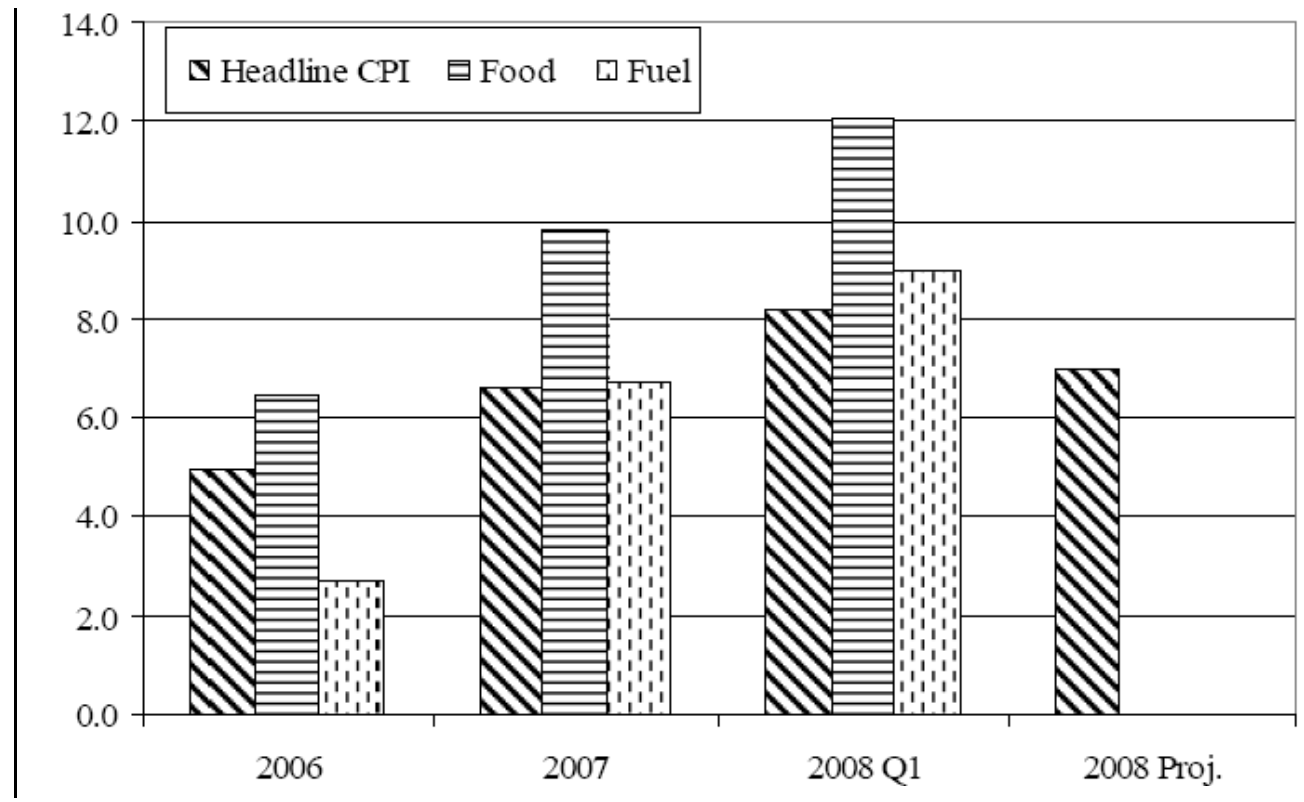

Source: From IMF (2008).

Figure 16. Targeted Measures to Contain Price Increases

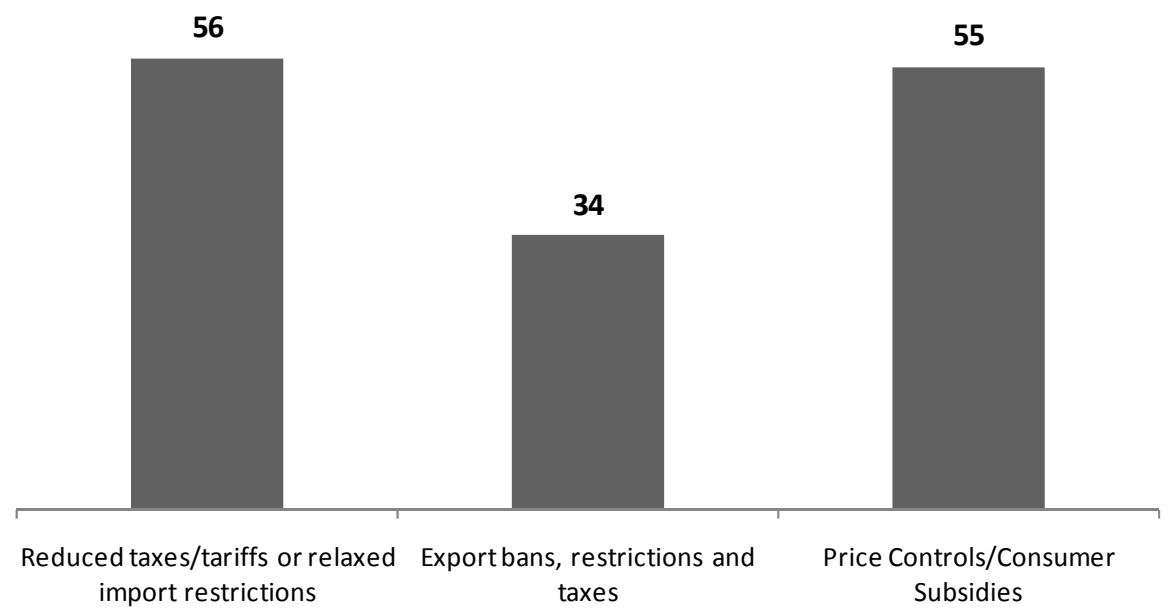

Source: Author's construction with information from the World Bank (2008d) and expanded with Trostle (2008), ADB (2008) and World Bank (2008e). 
Figure17. The Food Crisis: Safety Nets in Low and Middle-Income Countries

Source: Author's construction with information from the World Bank (2008d) and expanded with ADB (2008) and

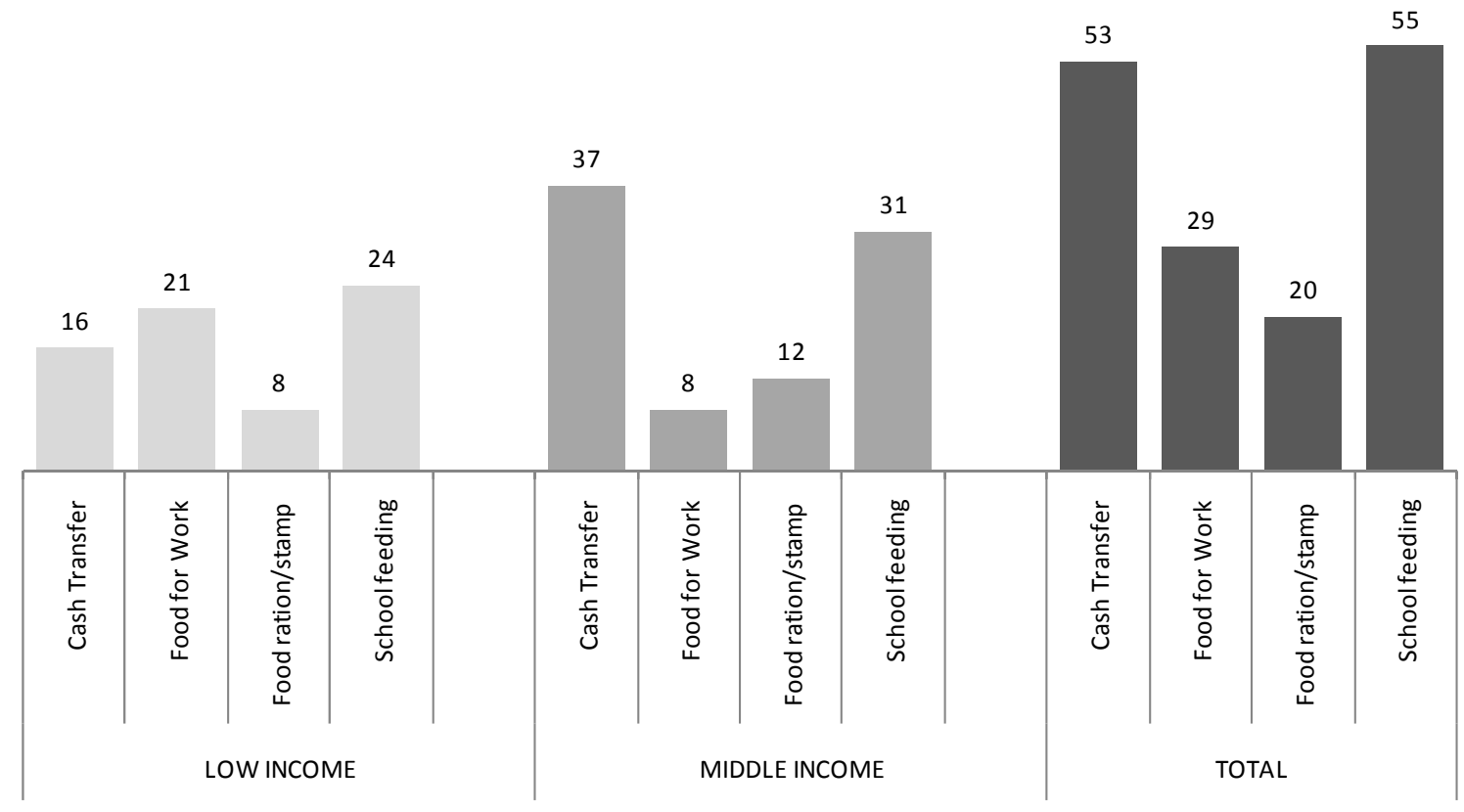

World Bank (2008e). Income classification data from the World Bank. The World Bank classifies 49 countries as low-income and 95 as middle-income; in the graph are those countries that implemented one or more programs (30 low income and 46 middle income countries ). 
Table 1. The Main Drivers of Rising Food Commodities Prices: A Summary of the Literature

\begin{tabular}{|c|c|c|}
\hline & Demand & Supply \\
\hline Policy Driven & $\begin{array}{l}\text { Excessively low prices in the past; market-and agricultural } \\
\text { support and R\&D policy driven } \\
\text { General subsidies, price controls, reduction of import } \\
\text { barriers and out-of-the ordinary purchases on the part of } \\
\text { governments in developing countries; defensive policy } \\
\text { response which exacerbates pressure on tight markets } \\
\text { Dollar depreciation; macroeconomic policy } \\
\text { Reduction in US interest rates; macroeconomic policy } \\
\text { Expansive macroeconomic policies resulting in too high } \\
\text { global economic growth; macroeconomic policy }\end{array}$ & $\begin{array}{l}\text { Excessively low prices in the past; market- and } \\
\text { agricultural support and R\&D policy driven } \\
\text { Diversion of food to biofuels production; market } \\
\text { and biofuels policy driven } \\
\text { Soaring energy prices; market and oil policy driven } \\
\text { Slowdown in output growth of agricultural } \\
\text { commodities; sectoral and R\&D policy driven } \\
\text { Bad weather and crop disease; natural causes and } \\
\text { policy(climate-change and disease-prevention) } \\
\text { driven } \\
\text { Export bans and export taxes; defensive policy } \\
\text { response which exacerbates pressure on tight } \\
\text { markets }\end{array}$ \\
\hline Market Driven & $\begin{array}{l}\text { Increase in food demand due to rising living standards; } \\
\text { market-driven } \\
\text { Excessively low prices in the past; market-and agricultural } \\
\text { support and } R \& D \text { policy driven } \\
\text { Speculation; market-driven and regulatory policy } \\
\text { Food hoarding and panic buying; defensive response which } \\
\text { exacerbates pressure on tight markets }\end{array}$ & $\begin{array}{l}\text { Diversion of food to biofuels production; market } \\
\text { and biofuels policy driven } \\
\text { Excessively low prices in the past; market- and } \\
\text { agricultural support and R\&D policy driven } \\
\text { Soaring energy prices; market and oil policy driven }\end{array}$ \\
\hline
\end{tabular}


Table 2. World Demand and Supply Summary: Corn, Wheat, Rice and Soybeans

\begin{tabular}{|c|c|c|c|c|}
\hline & CORN & RICE & WHEAT & OILSEEDS \\
\hline $\begin{array}{l}\text { HARVESTED AREA } \\
\text { (For all grains grew at } 0.4 \% \text { per } \\
\text { year between } 2000-07^{*} \text { ) }\end{array}$ & $\begin{array}{l}\text { Increased } 15 \% \text { from } \\
2002 / 03 \text { to } 2007 / 08\end{array}$ & & $\begin{array}{l}\text { Declined by } 10.4 \% \\
\text { between } 1980 / 81 \text { to } \\
2006 / 07 \text { but recovering }\end{array}$ & $\begin{array}{l}\text { Declined after 2005/06 but estimated to } \\
\text { rise again in 2008/09; land used for corn } \\
\text { (biofuels) in US; corn for in the US } \\
\text { increased } 37 \% \text { from } 2007 \text { to } 2008\end{array}$ \\
\hline $\begin{array}{c}\text { YIELD } \\
\text { (For all grains grew at } 1.3 \% \text { per } \\
\text { year between } 2000-07^{*} \text { ) }\end{array}$ & $\begin{array}{l}\text { Below trend } 2005 / 06 \\
\text { and } 2006 / 07 \text {, but on } \\
\text { trend for the rest }\end{array}$ & $\begin{array}{l}\text { Below trend } 2002 / 03 \\
2003 / 04,2004 / 05 \text { but on } \\
\text { trend for rest }\end{array}$ & $\begin{array}{l}\text { Below trend in } 2006 / 07 \\
\text { and } 2007 / 08 \text { but on trend } \\
\text { for rest }\end{array}$ & Below trend in $2007 / 08$ \\
\hline $\begin{array}{l}\text { FOOD CONSUMPTION } \\
\text { (For all grains grew at } 1.7 \% \text { per } \\
\text { year between } 2000-07^{*} \text { ) }\end{array}$ & $\begin{array}{l}\text { Grew at } 2.1 \% \text { per year } \\
\text { in } 2000-07 \text { and } 2.6 \% \\
\text { per year in } 1995-00^{*}\end{array}$ & $\begin{array}{l}\text { Grew at } 1 \% \text { per year in } 2000- \\
07 \text { and } 1.4 \% \text { per year in } 1995- \\
00^{*}\end{array}$ & $\begin{array}{l}\text { Grew at } 0.8 \% \text { per year in } \\
2000-07 \text { and } 1.4 \% \text { per } \\
\text { year in } 1995-00^{*}\end{array}$ & $\begin{array}{l}\text { Above trend due to increased demand in } \\
\text { China for animal feed purposes and rise } \\
\text { in human consumption of fats. }\end{array}$ \\
\hline INDUSTRIAL USE (biofuels ${ }^{\text {a) }}$ & $\begin{array}{l}\text { Above trend and } \\
\text { increasingly so since } \\
04 / 05_{-}^{\mathrm{b}} \\
\text { Use of maize for } \\
\text { ethanol from } 2004 \text { to } \\
2007 \text { was } 70 \% \text { of the } \\
\text { increase in global } \\
\text { maize production* }\end{array}$ & Not used for biofuels & Not used for biofuels & $\begin{array}{l}\text { Above trend for rapeseed and palm since } \\
2000 / 01 \text { and soybeans since } 2004 / 05 \text {. } \\
7 \% \text { of global vegetable oil supplies were } \\
\text { used for biodiesel production in } 2007 \\
\text { and about one-third of the increase in } \\
\text { consumption from } 2004 \text { to } 2007 \text { was due } \\
\text { to biodiesel*. } \\
\text { Industrial uses of vegetable oils grew by } \\
15 \% \text { per annum from } 2004 \text { to } 2007 \text {, } \\
\text { compared with } 4.2 \% \text { per annum for food } \\
\text { use*. } \\
\text { The share of industrial use of total use } \\
\text { rose from } 14.4 \% \text { in } 2004 \text { to } 18.7 \% \text { in } \\
2007^{*} \text {. }\end{array}$ \\
\hline CHINA AND INDIA & $\begin{array}{l}\text { No consumption surge } \\
\text { and no significant role } \\
\text { in international } \\
\text { markets }\end{array}$ & $\begin{array}{l}\text { No consumption surge; } \\
\text { China trades very little. India } \\
\text { was } 14 \% \text { of world exports } \\
\text { but fell to } 7-9 \% \text { in } 07 / 08 \text { and } \\
08 / 09 \text {. India's ban of rice } \\
\text { exports (Oct 2007) probably } \\
\text { had an effect on world prices }\end{array}$ & $\begin{array}{l}\text { No consumption surge (in } \\
\text { China, consumption } \\
\text { actually fell) and no } \\
\text { significant role in } \\
\text { international markets }\end{array}$ & $\begin{array}{l}\text { China's imports of palm oil and soybean } \\
\text { oil rose more sharply since } 02 / 03\end{array}$ \\
\hline STOCKS-TO-USE RATIO IN \% & $\begin{array}{l}\text { Lowest in 2008/09 } \\
\text { since } 1973 / 74\end{array}$ & $\begin{array}{l}\text { Declined to levels similar to } \\
\text { 1970s in 2004/05 and } \\
\text { subsequently leveled off }\end{array}$ & $\begin{array}{l}\text { Lowest in } 2007 / 08 \text { since } \\
\qquad 1960 / 61\end{array}$ & Lowest in $2004 / 05$ since 1970 s \\
\hline
\end{tabular}

Source: Author's elaboration based on “*” Mitchell (2008), Abbott et al. and own calculations based on USDA data.

a. Ethanol is produced from sugar crops, such as sugar cane or beets, or starchy crops such as maize. Biodiesel is produced from vegetable oils or animal fats.

b. The United States is the largest producer of ethanol from maize and is expected to use about 81 million tons for ethanol in the 2007/08 crop year. Canada, China and the European Union used roughly an additional 5 million tons of maize for ethanol in 2007 (USDA 2008a), bringing the total use of maize for ethanol to 86 million tons, about $11 \%$ of global maize production. The U.S. accounts for about one-third of global maize production and two-thirds of global exports and used 25 percent of its production for ethanol in 2007/08. The largest biodiesel producers were the European Union, the United States, Argentina, Australia, and Brazil, with a combined use of vegetable oils for biodiesel of about 8.6 million tons in 2007 compared with global vegetable oils production of 132 million tons. (Mitchell, 2008) 
Table 3. World Use of Corn and Vegetable Oils (in percent), 2004-2007

\begin{tabular}{|c|c|c|c|c|}
\hline & & Share 2004 & Share 2007 & $\begin{array}{c}\text { Share in } \\
\text { Growth, } \\
\text { 2004-2007 }\end{array}$ \\
\hline \multirow{3}{*}{ Corn } & Feed & 69 & 64 & 27 \\
\hline & FSI & 31 & 36 & 73 \\
\hline & Corn for Fuel* & 12 & 23 & 78 \\
\hline \multirow{3}{*}{ Vegetable Oils } & Food & 85 & 80 & 54 \\
\hline & Industrial & 14 & 19 & 46 \\
\hline & Other & 1 & 1 & -0.2 \\
\hline
\end{tabular}

Source: Own calculations with the PSD Database and the Feed Grains Database, USDA.

Notes: Data for vegetable oils is for the world. Data for corn is for the world except for the corn for fuel data $\left(^{*}\right)$ which is a subcategory for the US only. FSI refers to Food, Seed and Industrial uses. 
Table 4. Poverty Impacts of Recent Increases in Food Prices: A Summary of Available Studies

\begin{tabular}{|c|c|c|c|c|c|}
\hline & Ivanic and Martin (2008) & Wodon et al. (2008) & ADB (2008) & IADB (2008) & CEPAL (2008) \\
\hline RESULTS & $\begin{array}{l}\text { Poverty increases in all } \\
\text { countries with the } \\
\text { exception of Peru. The } \\
\text { 2005-2008Q1 price } \\
\text { increase scenario } \\
\text { increases national poverty } \\
\text { rates by } 4.5 \text { percentage } \\
\text { points on average } \\
\text { (calculating estimates for } \\
\text { all low income countries: } \\
\text { additional } 105 \text { million } \\
\text { people in poverty). }\end{array}$ & $\begin{array}{l}\text { Poverty increases. A } 50 \% \\
\text { increase in prices leads to } \\
\text { an average increase of the } \\
\text { headcount poverty of } 4.4 \\
\text { percentage points (or } 2.5 \\
\text { with producer impacts). An } \\
\text { average increase of } 3.5 \\
\text { percentage points at the } \\
\text { national level in SSA would } \\
\text { lead to to around } 30 \text { million } \\
\text { people in poverty }\end{array}$ & $\begin{array}{l}\text { Poverty and } \\
\text { inequality increase } \\
\text { in the short-term. In } \\
\text { the medium-term it } \\
\text { depends. A } 20 \% \text { food } \\
\text { price increase in } \\
\text { Philippines and } \\
\text { Pakistan increases } \\
\text { the number of poor } \\
\text { by } 5.65 \text { and } 14.67 \\
\text { million, respectively. }\end{array}$ & $\begin{array}{l}\text { Poverty increases by } \\
4.3 \text { percentage points } \\
\text { or } 21 \text { million additional } \\
\text { poor individuals (net } \\
\text { effect)*. For example, } \\
\text { total income poverty } \\
\text { increases by } 8 \\
\text { percentage points in } \\
\text { Guatemala (net effect } \\
\text { of intl. price increase), } \\
6.9 \text { in Mexico and } 6.5 \\
\text { in El Salvador }\end{array}$ & $\begin{array}{l}\text { Indigence increases } \\
\text { from } 12.7 \text { ( } 68.5 \text { million } \\
\text { people) to } 14.7 \text { ( } 79.1 \\
\text { million people) with } \\
\text { income effects. } \\
\text { Poverty increases } \\
\text { from } 35.1 \text { (189.5 } \\
\text { million people) to } 37 \\
\text { (199.6 million) with } \\
\text { income effects }\end{array}$ \\
\hline COUNTRIES & $\begin{array}{c}\text { Bolivia, Cambodia, } \\
\text { Madagascar, Malawi, } \\
\text { Nicaragua, Pakistan, } \\
\text { Peru, Vietnam and Zambia }\end{array}$ & $\begin{array}{c}\text { Burkina Faso, DRC, Ghana, } \\
\text { Gabon, Guinea, Liberia, } \\
\text { Mali, Niger, Nigeria, } \\
\text { Senegal, Sierra Leone, Togo }\end{array}$ & $\begin{array}{l}\text { Short-term Pakistan } \\
\text { and Philippines; } \\
\text { medium-term China } \\
\text { and Indonesia }\end{array}$ & $\begin{array}{l}\text { Nineteen countries in } \\
\text { LAC }\end{array}$ & $\begin{array}{l}\text { Estimates are for } \\
\text { Latin America and the } \\
\text { Caribbean as a whole }\end{array}$ \\
\hline METHOD & $\begin{array}{l}\text { Short-term impact; } \\
\text { Deaton's framework and } \\
\text { GTAP for wage effects }\end{array}$ & $\begin{array}{l}\text { Short-term impact; Deaton's } \\
\text { framework }\end{array}$ & $\begin{array}{c}\text { Short-term/partial } \\
\text { application of } \\
\text { Deaton's framework } \\
\text { with budget shares } \\
\text { only and no income } \\
\text { shares; medium term } \\
\text { impacts with CGE } \\
\text { model which } \\
\text { incorporates supply } \\
\text { response }\end{array}$ & $\begin{array}{l}\text { Upper bound increase } \\
\text { poverty line by } 30 \% \\
\text { (multiplication of } \\
\text { increase in world } \\
\text { prices of commodities } \\
\text { (.68) times average } \\
\text { share of six food } \\
\text { commodities (.435) } \\
\text { while rest of prices are } \\
\text { assumed unchanged). } \\
\text { Lower bound assumes } \\
\text { an increase in } \\
\text { agricultural workers' } \\
\text { income equal to world } \\
\text { price increases }\end{array}$ & $\begin{array}{l}\text { Not described in note } \\
\text { (will be published } \\
\text { shortly) }\end{array}$ \\
\hline $\begin{array}{l}\text { INCLUDES NET } \\
\text { SELLERS }\end{array}$ & Yes & $\begin{array}{l}\text { Upper bound estimates } \\
\text { include net-buyers only; } \\
\text { lower bound estimates } \\
\text { assume net-sellers receive } \\
\text { price increase in full }\end{array}$ & $\begin{array}{l}\text { Short-term estimates } \\
\text { includes buyers only; } \\
\text { medium-term CGE } \\
\text { should include effects } \\
\text { on net sellers }\end{array}$ & No & No \\
\hline WAGE EFFECTS & Yes & No & $\begin{array}{l}\text { Medium-term CGE } \\
\text { yes }\end{array}$ & $\begin{array}{l}\text { Assumes agricultural } \\
\text { workers' incomes rise }\end{array}$ & $\begin{array}{l}\text { Assumes everybody's } \\
\text { income rose } 5 \%\end{array}$ \\
\hline $\begin{array}{c}\text { SUBSTITUTION } \\
\text { EFFECT }\end{array}$ & No & No & $\begin{array}{l}\text { Medium-term CGE } \\
\text { yes }\end{array}$ & No & No \\
\hline PRICE INCREASE & $\begin{array}{l}\text { Three simulations: } 1.10 \% \\
\text { uniform increase/pass } \\
\text { through equal to } 1 ; 2 \text {. } \\
\text { 2005-07 actual FAO/pass } \\
\text { through .66; } 3.2005- \\
\text { 2008Q1** }\end{array}$ & $\begin{array}{l}\text { Simulate price increases of } \\
25 \% \text { and } 50 \% \text {; price } \\
\text { increases are the same for } \\
\text { all countries and all food } \\
\text { items }\end{array}$ & $\begin{array}{c}\text { Simulate food price } \\
\text { increases of } 10 \% \text {, } \\
20 \% \text { and } 30 \%\end{array}$ & $\begin{array}{l}\text { Simulates the impact of } \\
\text { the IFS estimate of } \\
\text { price increases for six } \\
\text { commodities from Jan } \\
06 \text { to March } 08 \\
(68.1 \%) \text {; full pass } \\
\text { through to domestic } \\
\text { prices. Also, simulates } \\
\text { price increases } \\
\text { estimated by central } \\
\text { hanks }\end{array}$ & $\begin{array}{l}\text { Assumes a } 15 \% \\
\text { increase in food } \\
\text { prices }\end{array}$ \\
\hline POVERTY LINE & 1 dollar a day in PPP & 1 dollar a day & $\begin{array}{l}\text { Country-specific } \\
\text { poverty lines }\end{array}$ & $\begin{array}{l}\text { Country-specific } \\
\text { poverty lines }\end{array}$ & $\begin{array}{l}\text { Country-specific } \\
\text { poverty lines for } \\
\text { moderate and } \\
\text { extreme poverty }\end{array}$ \\
\hline $\begin{array}{l}\text { POVERTY } \\
\text { MEASURE }\end{array}$ & $\begin{array}{l}\text { Headcount ratio and } \\
\text { poverty gap ratio }\end{array}$ & Headcount ratio & $\begin{array}{l}\text { Change in absolute } \\
\text { number of poor; Gini } \\
\text { coefficient }\end{array}$ & $\begin{array}{l}\text { Headcount ratio and } \\
\text { poverty gap ratio }\end{array}$ & $\begin{array}{l}\text { Headcount ratio and } \\
\text { number of poor } \\
\text { individuals }\end{array}$ \\
\hline $\begin{array}{l}\text { ROBUSTNESS } \\
\text { CHECKS }\end{array}$ & $\begin{array}{c}\text { Poverty line; price } \\
\text { increases; labor market } \\
\text { segmentation }\end{array}$ & $\begin{array}{l}\text { Simulation of two levels of } \\
\text { price increases and upper } \\
\text { and lower bounds }\end{array}$ & $\begin{array}{l}\text { Simulation of three } \\
\text { levels of price } \\
\text { increases }\end{array}$ & $\begin{array}{l}\text { None that are } \\
\text { mentioned }\end{array}$ & $\begin{array}{l}\text { None that are } \\
\text { mentioned }\end{array}$ \\
\hline
\end{tabular}

* Own calculations based on the paper.

** For the 2005 to 2008.Q1 authors attempted to at what had actually happened to domestic prices. If a currency had appreciated against the USD, then the domestic price increase for these commodities was assumed to be smaller than the increase in $\$$ and we first made that adjustment. If other prices had increased, and we tracked this using inflation over the period, then the increase in food prices had to be compared relative to that increase in prices. So there were two adjustments-- one for the exchange rate and one for increases in the general price level. 


\section{References}

Abbott, Philip C.; Christopher Hurt and Wallace E. Tyner (2008) "What's Driving Food Prices”. Issue Report, Farm Foundation.

Ackah, Charles and Simon Appleton (2007) "Food Price Changes and Consumer Welfare in Ghana in the 1990s." Discussion Papers 07/03, University of Nottingham, CREDIT.

Asian Development Bank (2008) "Food Prices and Inflation in Developing Asia: Is Poverty Reduction Coming to an End?” Special Report, Asian Development Bank.

Aksoy, M. Ataman and Aylin Isik-Dikmelik (2008) “Are Low Food Prices Pro-Poor? Net Food Buyers and Sellers in Low-Income Countries.” Policy Research Working Paper 4642, The World Bank.

Baffes, John (1997) "Explaining Stationary Variable with Non-stationary Regressors.” Applied Economics Letters, 4(1997):69-75.

Barrett, Christopher B. and Paul A. Dorosh (1996) "Farmers' Welfare and Changing Food Prices: Nonparametric Evidence from Rice in Madagascar.” American Journal of Agricultural Economics, Vol. 78, No. 3: 656-669.

Byerlee, Derek, Robert Myers and Thomas Jayne (2006) "Managing Food Price Risks and Instability in an Environment of Market Liberalization." Report No. 32727-GLB, Agriculture and Rural Development Department. The World Bank: Washington, D.C.

Calvo, Guillermo (2008) "Exploding commodity prices, lax monetary policy, and sovereign wealth funds.” VOX, June $20^{\text {th }}$. Available at:

http://www.voxeu.org/index.php?q=node/1244.

Center for Strategic and International Studies (2008) “A Call For A Strategic U.S. Approach To The Global Food Crisis, A Report of the CSIS Task Force on the Global Food Crisis Core Findings and Recommendations." Report of the Center for Strategic and International Studies.

Comision Economica para America Latina y el Caribe, CEPAL (2008) "Latin America and the Caribbean in the New International Economic Environment." Report of the Comision Economica para America Latina y el Caribe (Economic Commission for Latin America and the Caribbean.)

Christiaensen, Luc and Lionel Demery (2007) "Down to Earth. Agriculture and Poverty Reduction in Africa. Directions in Development” Directions in Development, The World Bank: Washington, D.C.

Cline, William (2003) "Trading Up: Trade Policy and Global Poverty.” Center for Global Development Brief. 
Coady, David; Paul Dorosh and Bart Minten (2008) "Evaluating Alternative Approaches to Poverty Alleviation in Madagascar: Rice Tariffs versus Targeted Transfers." Mimeographed.

Collins, Keith (2008) "The Role of Biofuels and Other Factors in Increasing Farm and Food Prices: A Review of Recent Development with a Focus on Feed Grain Markets and Market Prospects.” Supporting material for a review conducted by Kraft Foods Global, Inc. of the current situation in farm and food markets, June. Unpublished document.

Coyle, William (2007) “The Future of Biofuels: A Global Perspective.” Amber Waves, November. United States Department of Agriculture.

Dawe, D. (2008) "Have recent increases in international cereal prices been transmitted to domestic economies? The Experience in seven large Asian countries.” ESA Working Paper No. 08-03, Food and Agriculture Organization.

Deaton, Angus (1989) "Rice Prices and Income Distribution in Thailand: A NonParametric Analysis.” The Economic Journal, Vol. 99, No. 395, Supplement: Conference Papers: 1-37.

De Janvry, Alain and Elisabeth Sadoulet (2008) "How to manage a quick response to the food crisis in poor countries with weak policy instruments?” Unpublished document.

Dervis, Kemal (2008) “Q \& A with Kemal Dervis, head of the UN Development Program.” In “Managing Globalization” (Blog) by Daniel Altman, August 13th, International Herald Tribune.

Dessus, Sebastien, Santiago Herrera, and Rafael de Hoyos (2008) “The Impact of Food Inflation on Urban Poverty and Its Monetary Cost: Some Back-of-the-Envelope Calculations?,” World Bank Policy Research Working Paper 4666, Washington, DC.

Elliott, Kimberly (2008) "Biofuels and the Food Price Crisis: A Survey of the Issues." Working Paper Number 151, Center for Global Development.

Food and Agriculture Organization (2008a) "Crop Prospects and Food Situation”. GIEWS Report No. 2.

Food and Agriculture Organization (2008b) "Crop Prospects and Food Situation”. GIEWS Report No. 3.

Fleshman, Michael (2008) "Africa struggles with soaring food prices. From emergency reactions to farming investments.” Africa Renewal, Vol.22 \#2 (July): 12. Available at: http://www0.un.org/ecosocdev/geninfo/afrec/vol22no2/222-africa-struggles-with-foodprices.html.

Fogel, Robert (1991) "New Findings on Secular Trends in Nutrition and Mortality: Some Implications for Population Theory." Unpublished manuscript, University of Chicago. 
Fogel, Robert W. (1994) "Economic Growth, Population Theory, and Physiology: The Bearing of Long-Term Processes on the Making of Economic Policy.” The American Economic Review, Vol. 84, No. 3, (Jun.): 369-395.

Frances Stewart, Valpy Fitzgerald and Associates, eds. (2001) "War and Underdevelopment: Volume 1: The economic and social consequences of conflict.” Oxford: Oxford University Press: 21-38.

Frankel, Jeffrey (2006) “The Effect of Monetary Policy on Real Commodity Prices.” Working Paper 12713, National Bureau of Economic Research.

Frankel, Jeffrey (1986) "Expectations and Commodity Price Dynamics: The Overshooting Model." American Journal of Agricultural Economic, 68, no. 2: 344-348.

Frankel, Jeffrey (2008a) “Fed Modesty Regarding Its Role in High Commodity Prices.” Jeff Frankel's Weblog, May $21^{\text {st }}$. Available at:

http://content.ksg.harvard.edu/blog/jeff_frankels_weblog/category/commodities/.

Frankel, Jeffrey (2008b) “An Explanation for Soaring Commodity Prices.” VOX, March 25th. Available at: http://www.voxeu.org/index.php?q=node/1002.

Frankel, Jeffrey (2008c) "Monetary policy and commodity prices.” VOX, March 29th. Available at: http://www.voxeu.org/index.php?q=node/1178.

Gately, Dermot and Hillard G. Huntington (2001) "The Asymmetric Effects of Changes in Price and Income on Energy and Oil Demand.” Economics Research Report, C.V. Starr Center for Applied Economics, New York University.

George, Alexander L. and Andrew Bennett (2005) "Case Studies and Theory Development in the Social Sciences.” MIT Press, Chapter 10.

Gilbert, Christopher (1989) "The Impact of Exchange Rate Changes and Developing Country Debt on Commodity Prices.” Economic Journal, 99:773-784.

Haggblade, S.; P.B. Hazell, and P.A. Dorosh (2007) "Sectoral Growth Linkages Between Agriculture and the Rural Nonfarm Economy." In "Transforming the Rural Nonfarm Economy,” (Haggblade, S, S.P. Hazell, and P.A. Dorosh [eds]), John Hopkins University Press, Baltimore.

Hoekman, Bernard M., and Marcelo Olarreaga, eds. (2007) "Global Trade and Poor Nations: The Poverty Impacts and Policy Implications of Liberalization.” Washington: Brookings Institution Press.

International Food Policy Research Institute (2003) "A Level Playing Field for Poor Farmers.” Ifpri Forum, March.

International Monetary Fund (2008) "Food and Fuel Prices-Recent Developments, Macroeconomic Impact, and Policy Responses.” Prepared by the Fiscal Affairs, Policy Development and Review, and Research Departments. International Monetary Fund Report. 
Ivanic, Maros and Martin, Will (2008) "Implications of higher global food prices for poverty in low-income countries.” Policy Research Working Paper Series 4594, The World Bank.

Jayne,T.; T. Yamano; J.Nyoto and T. Awuor (2001) "Do Farmers Really Benefit from High Food Prices? Balancing Rural Interests in Kenya's Maize Pricing and Marketing Policy." Draft Working Paper 2B. Mimeographed.

Ki-moon, Ban (2008) “The New Face Of Hunger”. The Washington Post, March 12: A19.

Krichene, Noureddine (2008) "Recent Inflationary Trends in World Commodities Markets.” International Monetary Fund Working Paper WP/08/130.

Krugman, Paul (2008) "Commodities and speculation: metallic (and other) evidence." New York Times’ Blog, April 20"

Latin American Shadow Financial Regulatory Committee, CLAAF (2008) "Sailing in a Stormy Sea: Latin America's Response to Global Financial Turmoil and the Food Price Crisis.” CLAAF Statement 18, May $21^{\text {st }}$.

Lipsky, John (2008) "Commodity Prices and Global Inflation.” Remarks at the Council on Foreign Relations, New York City, May 8.

Lustig, Nora (1986) “Food Subsidy Programs in Mexico.” Working Paper No. 3, International Food Policy Research Institute, Washington, D.C., January.

Lustig, Nora (2008) "Las causas y consecuencias de la carestía de los alimentos.” Serie Brief No. 40, Red Latinoamericana de Política Comercial (LATN).

Lustig, Nora (2008) "Las papas queman: causas y consecuencias de la carestía alimentaria.” NEXOS, Julio.

McPhail, Lihong Lu and Bruce A. Babcock (2008) "Short-Run Price and Welfare Impacts of Federal Ethanol Policies.” Working Paper 08-WP 468, Center for Agricultural and Rural Development, Iowa State University.

Mellor, J. W. (1978) "Food Price Policy and Income Distribution in Low-Income Countries.” Economic Development and Cultural Change, 1: 1-26.

Mitchell, Donald (2008) “A note on rising food prices.” Policy Research Working Paper 4682, The World Bank.

Mitchell, Donald (2008) “A Note on Rising Food Prices”. Policy Research Working Paper 4682. The World Bank.

Mundell, Robert (2002) "Commodity Prices, Exchange Rates and the International Monetary System.” Consultation on Agricultural Commodity Price Problems, Food and Agriculture Organization.

Nafziger, E.W., F. Stewart, and R. Väyrynen, eds (2000) "War, Hunger, and Displacement: The Origins of Humanitarian Emergencies. 2 vols.” Queen Elizabeth 
House Series in Development Economics and UNU/World Institute for Development Economics Research Studies in Development Economics. Oxford: Oxford University Press.

Narayan, Deepa; Raj Patel; Kai Schafft; Anne Rademacher and Sarah Koch-Schulte (2000) “Voices of the Poor: Can Anyone Hear Us?” New York, N.Y.: Published for the World Bank, Oxford University Press.

Naylor, Rosamond L. and Walter P. Falcon (2008) “A New Variety of Food Crisis.” Unpublished document.

Office of Development Studies-United Nations Development Programme (2008) “A Preliminary Anatomy of the Unfolding Global Food Crisis.” United Nations Development Programme. Unpublished document.

Organization for Economic Co-operation and Development (2008) "Economic Assessment of Biofuel Support Policies.” Report of the Directorate for Trade and Agriculture, Organization for Economic Co-operation and Development.

Organization for Economic Co-operation and Development -Food and Agriculture Organization (2007) “Agricultural Outlook 2007-2016.” OECD-FAO Report.

Polaski, Sandra (2008) "Rising Food Prices, Poverty, and the Doha Round.” Policy Outlook, March. Carnegie Endowment for International Peace.

Pinstrup-Andersen (1987) “Food Prices and the Poor.” In J. Price Gittinger, Joanne Leslie and Caroline Joisington "Food Policy. Integrating Supply, Distribution and Consumption”, Johns Hopkins University Press.

Ravallion, M. (1989) "Do Price Increases for Staple Foods Help or Hurt the Rural Poor." PPR working Paper WPS 167, World Bank, Washington D.C.

Ravallion, M., and D. van de Walle (1991) "The impact on poverty of food pricing reforms: A welfare analysis for Indonesia.” Journal of Policy Modeling 13 (2): 281299.

Ravallion, Martin (1990) "Rural Welfare Effects of Food Price Changes Under Induced Wage Responses: Theory and Evidence for Bangladesh.” Oxford Economic Papers. Oxford: Jul 1990. Vol. 42, Iss. 3: 574 (12 pages).

Regional Bureau for Latin America and the Caribbean-United Nations Development Programme (2008) "Food Prices, Vulnerability and Public Policy Responses in Latin America and the Caribbean.” Regional Bureau for Latin America and the Caribbean, United Nations Development Programme. Unpublished document.

Robles, Marcos; Jose Cuesta; Suzanne Duryea; Ted Enamorado; Alberto Gonzales, and Victoria Rodríguez (2008) "Rising Food Prices and Poverty in Latin America: Effects of the 2006-2008 Price Surge.” Inter-American Development Bank.

Rogoff, Kenneth (2008) “The world cannot grow its way out of this slowdown.” July 29, Financial Times. Available at: http://www.ft.com/cms/s/0/29a40a90-5d6f-11dd8129-000077b07658.html. 
Rojas-Suarez, Liliana (2008) "The Right Response in Latin America to Oil and Food Price Pressures: Fight Inflation Now!” Essay, Center for Global Development.

Rosegrant, Mark W. (2008) "Biofuels and Grain Prices: Impacts and Policy Responses.” Testimony for the U.S. Senate Committee on Homeland Security and Governmental Affairs, International Food Policy Research Institute, May $7^{\text {th }}$.

Rosegrant, Mark W.; Tingju Zhu; Siwa Msangi; Timothy Sulser (2008) “Biofuels and Cereal Prices: How Much has Growth in Biofuel Production Influenced World Cereal Prices?” International Food Policy Research Institute. Unpublished document.

Rosen, Stacey; Shahla Shapouri; Kathryn Quanbeck, and Birgit Meade (2008) "Food Security Assessment 2007”. A Report from the Economic Research Service, United States Department of Agriculture.

Schuh, G. Edward (1987) “The Changing Context of Food Policy.” In J. Price Gittinger, Joanne Leslie and Caroline Hoisington, eds, "Food Policy. Integrating Supply, Distribution and Consumption,” Johns Hopkins University Press (for The World Bank).

Sistema Económico Latinoamericano y del Caribe, SELA (2008) "The increase in food prices: SELA's response.” SELA Report.

Sen, Amartya (1981) Poverty and Famines. An Essay on Entitlement and Depravation. International Labour Organization, Clarendon Press, Oxford.

Seshan, Ganesh and Dina Umali-Deininger (2007) "Agriculture and Import Liberalization and Household Welfare in Sri Lanka." Mimeographed.

Slayton, Tom and Peter Timmer (2008) "Japan, China and Thailand Can Solve the Rice Crisis-but US leadership is needed." CGD Notes, Center for Global Development.

Subramanian, Arvind (2008) "Hearing on Contributing Factors and International Responses to the Global Food Crisis.” Statement before the U.S. House of Representatives Committee on Financial Services, Center for Global Development and Peterson Institute for International Economics.

Tilly, C. (1975) "Food supply and public order in modern Europe.” In, C. Tilly, ed., "The Formation of Nation States in Western Europe." Princeton: Princeton University Press: 380-455.

Tilly, Louise A. (1983) "Food Entitlement, Famine, and Conflict.” Journal of Interdisciplinary History, Vol. 14, No. 2, Hunger and History: The Impact of Changing Food Production and Consumption Patterns on Society, (Autumn): 333- 349.

Timmer, C.; W. Falcon, and S. Pearson (1983) “Food Policy Analysis.” Johns Hopkins University Press, 1983: 1- 301.

Timmer, Peter (2008) “The causes of high food prices.” Unpublished document.

Timmer, Peter (2008a) “Japan ducks rice-crisis solution”. July $18^{\text {th }}$, Asia Times. Available at: http://www.atimes.com/atimes/Global_Economy/JG18Dj02.html. 
Trairatvorakul (1984) “The Effects on Income Distribution and Nutrition of Alternative Rice Price Policies in Thailand.” Research Report 46, International Food Policy Research Institute, November 1984.

United Nations Conference on Trade and Development, UNCTAD (2008) “Addressing The Global Food Crisis: Key Trade, Investment And Commodity Policies In Ensuring Sustainable Food Security And Alleviating Poverty.” A Note by the UNCTAD

Secretariat at the High-Level Conference on World Food Security: The Challenges of Climate Change and Bioenergy (3 - 5 June 2008, Rome, Italy).

United States Government Accountability Office (2008) "Insufficient Efforts by Host Governments and Donors Threaten Progress to Halve Hunger in Sub-Saharan Africa by 2015.” GAO Report to Congressional Requesters.

Von Braun, Joachim (2007) "The World Food Situation: New Driving Forces and Required Actions.” Food Policy Report No. 18, International Food Policy Research Institute.

Von Braun, Joachim (2008a) "Biofuels, International Food Prices, and the Poor.” International Food Policy Research Institute, Testimony to the United States Senate Committee on Energy and Natural Resources, June $12^{\text {th }}$.

Von Braun, Joachim et al. (2008b) "High Food Prices: The What, Who, and How of Proposed Policy Actions.” Policy Brief, International Food Policy Research Institute.

Von Braun, Joachim et al. (2008c) “Rising Food Prices: What Should Be Done?” Policy Brief, International Food Policy Research Institute.

Von Braun, Joachim (2008d) "High Food Prices and the Impacts on the Poor in Latin America.” Presentation at the Inter-American Dialogue, Washington D.C., July 21, International Food Policy Research Institute.

Warr, Peter (2005) "Food Policy and Poverty in Indonesia: a General Equilibrium Analysis." Departmental Working Papers 2005-03, Australian National University. Economics RSPAS.

Wodon, Quentin et al. (2008) “The Food Price Crisis in Africa: Impact On Poverty And Policy Responses.” World Bank (mimeo).

World Bank (2007) “World Development Report 2008: Agriculture for Development.” World Development Report, The World Bank.

World Bank (2008a) “Rising Global Food Prices.” The World Bank’s Latin America and Caribbean Region Position Paper. Washington, DC: World Bank. Unpublished document.

World Bank (2008b) "Addressing the Food Crisis: The Need for Rapid and Coordinated Action.” Background Paper for the G8 Ministers of Finance Meeting. Washington, DC: World Bank.

World Bank (2008d) “Double Jeopardy: Responding to High Food and Fuel Prices.” G8 Hokkaido-Toyako Summit. Washington, DC: World Bank. 
World Bank (2008e) "Food Price Inflation and its Effects on Latin America and the Caribbean." Washington, DC: World Bank.

Zoellick, Robert B. (2008) “A Challenge of Economic Statecraft.” A speech to the Center for Global Development, Washington, DC (April). 